\title{
Airborne observations of trace gases over boreal Canada during BORTAS: campaign climatology, air mass analysis and enhancement ratios
}

\author{
S. J. O'Shea ${ }^{1}$, G. Allen ${ }^{1}$, M. W. Gallagher ${ }^{1}$, S. J.-B. Bauguitte ${ }^{2}$, S. M. Illingworth ${ }^{1}$, M. Le Breton ${ }^{1}$, J. B. A. Muller ${ }^{1}$, \\ C. J. Percival ${ }^{1}$, A. T. Archibald ${ }^{3}$, D. E. Oram ${ }^{4}$, M. Parrington ${ }^{5, *}$, P. I. Palmer ${ }^{5}$, and A. C. Lewis ${ }^{6}$ \\ ${ }^{1}$ School of Earth, Atmospheric and Environmental Sciences, University of Manchester, Oxford Road, Manchester, \\ M13 9PL, UK \\ ${ }^{2}$ Facility for Airborne Atmospheric Measurements (FAAM), Building 125, Cranfield University, Cranfield, Bedford, \\ MK43 0AL, UK \\ ${ }^{3}$ Centre for Atmospheric Science, University of Cambridge, Cambridge, CB2 1EW, UK \\ ${ }^{4}$ National Centre for Atmospheric Science, School of Environmental Sciences, University of East Anglia, Norwich, \\ NR4 7TJ, UK \\ ${ }^{5}$ School of GeoSciences, The University of Edinburgh, Edinburgh, EH9 3JN, UK \\ ${ }^{6}$ National Centre for Atmospheric Science (NCAS), University of York, Heslington, York, YO10 5DD, UK \\ *now at: European Centre for Medium-Range Weather Forecasts, Shinfield Park, Reading, RG2 9AX, UK
}

Correspondence to: S. J. O'Shea (sebastian.oshea@manchester.ac.uk)

and G. Allen (grant.allen@manchester.ac.uk)

Received: 30 April 2013 - Published in Atmos. Chem. Phys. Discuss.: 29 May 2013

Revised: 25 October 2013 - Accepted: 14 November 2013 - Published: 19 December 2013

\begin{abstract}
In situ airborne measurements were made over eastern Canada in summer 2011 as part of the BORTAS experiment (Quantifying the impact of BOReal forest fires on Tropospheric oxidants over the Atlantic using Aircraft and Satellites). In this paper we present observations of greenhouse gases $\left(\mathrm{CO}_{2}\right.$ and $\left.\mathrm{CH}_{4}\right)$ and other biomass burning tracers $\left(\mathrm{CO}, \mathrm{HCN}\right.$ and $\left.\mathrm{CH}_{3} \mathrm{CN}\right)$, both climatologically and through case studies, as recorded on board the FAAM BAe-146 research aircraft.

Vertical profiles of $\mathrm{CO}_{2}$ were generally characterised by depleted boundary layer concentrations relative to the free troposphere, consistent with terrestrial biospheric uptake. In contrast, $\mathrm{CH}_{4}$ concentrations were found to rise with decreasing altitude due to strong local and regional surface sources. BORTAS observations were found to be broadly comparable with both previous measurements in the region during the regional burning season and with reanalysed composition fields from the EU Monitoring Atmospheric Composition and Change (MACC) project. We use coincident tracer-tracer correlations and a Lagrangian trajectory model
\end{abstract}

to characterise and differentiate air mass history of intercepted plumes. In particular, $\mathrm{CO}, \mathrm{HCN}$ and $\mathrm{CH}_{3} \mathrm{CN}$ were used to identify air masses that have been recently influenced by biomass burning.

Examining individual cases we were able to quantify emissions from biomass burning. Using both near-field $(<1$ day) and far-field ( $>1$ day) sampling, boreal forest fire plumes were identified throughout the troposphere. Fresh plumes from fires in northwestern Ontario yield emission factors for $\mathrm{CH}_{4}$ and $\mathrm{CO}_{2}$ of $8.5 \pm 0.9 \mathrm{~g}$ ( $\mathrm{kg}$ dry matter) ${ }^{-1}$ and $1512 \pm 185 \mathrm{~g}$ (kg dry matter $)^{-1}$, respectively. We have also investigated the efficacy of calculating emission factors from far-field sampling, in which there might be expected to be limited mixing with background and other characteristic air masses, and we provide guidance on best practice and limitations in such analysis. We have found that for measurements within plumes that originated from fires in northwestern Ontario 2-4 days upwind, emission factors can be calculated that range between $1618 \pm 216$ and $1702 \pm 173 \mathrm{~g}$ 
(kg dry matter) ${ }^{-1}$ for $\mathrm{CO}_{2}$ and $1.8 \pm 0.2$ and $6.1 \pm 1 \mathrm{~g}(\mathrm{~kg}$ dry matter $)^{-1}$ for $\mathrm{CH}_{4}$.

\section{Introduction}

The global burden of greenhouse gases (GHGs) has increased significantly over the last century. This has mostly been attributed to growth and changes in anthropogenic emissions (Forster and Ramaswamy, 2007). However, trends in globally averaged concentrations alone are not sufficient to predict future changes in the abundance of GHGs and plan mitigation strategies for emission controls. Therefore, the distribution of GHGs needs to be known at a much finer scale, whilst both sources and sinks must be resolved in terms of their process, temporal and spatial variability (Marquis and Tans, 2008; Dlugokencky et al., 2011).

Biomass burning (BB) has long been known to play an important role in the budgets of a variety of atmospheric trace gases and particles, including GHGs (Crutzen et al., 1979; Seiler and Crutzen, 1980). It is estimated that between 1997 and 2009 , global BB released on average $2.0 \mathrm{Pg} \mathrm{yr}^{-1}$ of carbon (C) into the atmosphere (van der Werf et al., 2010). However, there is a large degree of uncertainty and variability in the contributions made by particular regions, both intra- and inter-annually. This is due to the unique and episodic nature of individual fire events and the necessary assumptions inherent in the monitoring of such emissions. Broadly, however, it has been suggested (van der Werf et al., 2010) that Africa makes the largest contribution to total C emissions (54\%), followed by South America (15\%). Fires in boreal regions have also been suggested to be responsible for large changes in atmospheric composition. For example, forest fires in Russia alone have been causally linked to the accelerated growth rate of global mean $\mathrm{CH}_{4}$ concentrations that was observed in 1998, 2002 and 2003 (Dlugokencky et al., 2001; Langenfelds et al., 2002; Simpson et al., 2006).

Climate change has the potential to further increase the impact of wildfires on trace gas budgets. Canadian boreal fire frequency and annual burn area have shown an upward trend since satellites were first able to monitor fires in the 1970s, which is thought to be due to rising mean summer temperatures in the region observed over the same period (Gillett et al., 2004). Current research suggests that this trend will continue: estimates using global circulation models suggest that fires in Canada will be $30 \%$ more frequent by 2030 and could be up to $150 \%$ more common by the end of the century (Wotton et al., 2010).

As well as being a major source of greenhouse gases, BB can significantly reduce air quality on local to hemispheric scales, with emissions advected by synoptic weather systems (Damoah et al., 2004). On occasion these long-range transported pollutants can lead to exceedances of air quality standards many 1000 s of kilometres from the fire source (Jaffe et al., 2004). BB influence can also dominate the abun- dance of various volatile organic compounds (VOCs) measured at remote background sites (Lewis et al., 2013). Under certain burning and meteorological conditions, vertical mixing can be dramatically enhanced by fires (known as pyroconvection), allowing rapid transport of pyrogenic species and particulates into the upper troposphere/lower stratosphere (UTLS), resulting in perturbations to the Earth's radiation budget, cloud microphysics and stratospheric chemistry (Damoah et al., 2006; Cammas et al., 2009). However, much work is still needed to fully understand the relative impact of BB on overall atmospheric composition (Wotawa and Trainer, 2000; Monks et al., 2009); a particular area of disagreement in the literature is whether BB results in the net production of tropospheric $\mathrm{O}_{3}$ (Jaffe and Wigder, 2012; Parrington et al., 2013).

The BORTAS (Quantifying the impact of BOReal forest fires on Tropospheric oxidants over the Atlantic using Aircraft and Satellites) project was conceived to investigate the distribution and composition of the outflow from North American BB using a combination of ground-based, aircraft and satellite measurements, and to use chemistry transport models to quantify its impact on tropospheric chemistry. The UK's Facility for Airborne Atmospheric Measurements (FAAM) BAe-146 research aircraft was deployed to Nova Scotia, Canada, where a number of BB plumes of differing ages were sampled (0 to 10 days). A comprehensive description of the motivation for the BORTAS experiment can be found in Palmer et al. (2013), along with a description of the FAAM BAe-146 instrumental payload, a general summary of the flights that took place during BORTAS, and the prevailing synoptic meteorological conditions.

This paper presents the in situ observations of $\mathrm{CO}_{2}$ and $\mathrm{CH}_{4}$ that were made using cavity-enhanced absorption spectroscopy on the FAAM BAe-146 as part of the BORTAS project. In Sect. 2, we describe measurement techniques and analysis methodologies. Section 3 presents bulk statistics using all available measurements; BORTAS measurements are shown to be in agreement with both previous measurements and modelled concentrations. Section 4 identifies individual biomass burning events where enhancement ratios and emission factors can be quantified. The paper is briefly summarised in Sect. 5.

\section{Data sources and analysis methodology}

\subsection{Aircraft sampling}

The airborne measurement component of BORTAS consisted of 15 flights by the FAAM BAe-146, conducted between 12 July and 3 August 2011. The whole flight campaign comprised approximately $79 \mathrm{~h}$ in total, with each flight lasting between 3 and $8 \mathrm{~h}$ in duration. These flights are nominally referenced as B618 to B632 and their geographic coverage is 

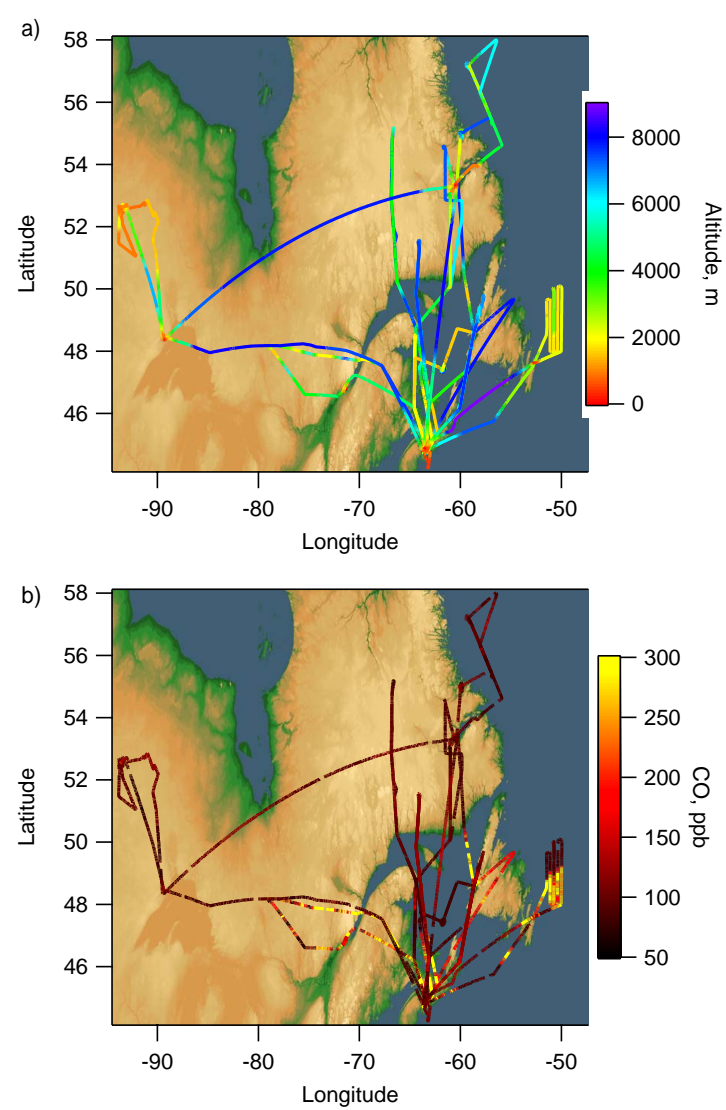

Fig. 1. The geographic coverage of flights during BORTAS, 12 July to 3 August, 2011 (excluding the Atlantic transits) colour-coded by (a) altitude and (b) $\mathrm{CO}$ as a marker for BB.

shown in Fig. 1. For the majority of the campaign the aircraft was based in Halifax, Nova Scotia (Palmer et al., 2013).

$\mathrm{CO}_{2}$ and $\mathrm{CH}_{4}$ dry air mole fractions were determined using an adapted system based on a fast greenhouse gas analyser (FGGA) from Los Gatos Research Inc., which uses the cavity-enhanced absorption spectroscopy technique. O'Shea et al. (2013) provide an extensive description of this system along with the associated calibration standards, data processing and quality control procedures that were performed. Inflight calibrations were frequently performed using three gas standards, all of which are traceable to the WMO (World Meteorological Organization)-recommended scales for $\mathrm{CO}_{2}$ and $\mathrm{CH}_{4}$ measurements (WMO-X2007 and NOAA 2004). Through summing all known uncertainties the accuracy of the measurements can be estimated to be $\pm 1.28 \mathrm{ppb}$ for $\mathrm{CH}_{4}$ and $\pm 0.17 \mathrm{ppm}$ for $\mathrm{CO}_{2}$. This represents less than $0.1 \%$ and $0.05 \%$ of typical background concentrations, respectively. The $1 \mathrm{~Hz}$ precision is $2.48 \mathrm{ppb}(1 \sigma)$ for $\mathrm{CH}_{4}$ and $0.66 \mathrm{ppm}$ $(1 \sigma)$ for $\mathrm{CO}_{2}$.

We shall also use concentration data for a range of other trace gases (including those principally emitted by BB) for air mass history as described in Sect. 2.2. This includes car- bon monoxide (CO), a product and tracer of incomplete combustion processes, and hydrogen cyanide $(\mathrm{HCN})$ and acetonitrile $\left(\mathrm{CH}_{3} \mathrm{CN}\right)$, both key tracers of $\mathrm{BB}$. $\mathrm{CO}$ was measured using a vacuum ultraviolet florescence analyser (AL5002, Aerolaser GmbH, Germany; Gerbig et al., 1999). Precision of the $1 \mathrm{~Hz} \mathrm{CO}$ measurements is $\pm 1.5 \mathrm{ppb}$ at $100 \mathrm{ppb}$; total uncertainty is estimated to be $\pm 2 \%$.

$\mathrm{HCN}$ was monitored using chemical ionisation mass spectrometry (CIMS), with a limit of detection of $5 \mathrm{ppt}$ and a total uncertainty estimated to be $10 \%$ at $3 \mathrm{~s}$ time resolution (Le Breton et al., 2013). $\mathrm{CH}_{3} \mathrm{CN}$ concentrations were determined using a proton transfer reaction mass spectrometer (PTR-MS), with a 9 to $20 \mathrm{~s}$ time response depending on the number of species that are measured, and the $\mathrm{CH}_{3} \mathrm{CN}$ measurement uncertainty is estimated to be $\pm 9 \%$ (Murphy et al., 2010). For a description of all other measurements made on the FAAM BAe-146 refer to Palmer et al. (2013).

\subsection{Analysis methodology}

In Sects. 3 and 4, we will discuss measurements of various trace gases in the context of their air mass history. To distinguish between air masses we make use of a variety of coincident tracer measurements made on board the FAAM BAe-146. As well as being a tracer for incomplete combustion, $\mathrm{CO}$ is also produced from the oxidation of hydrocarbons. Reaction with the hydroxyl radical $(\mathrm{OH})$ is the major atmospheric sink.

$\mathrm{HCN}$ and $\mathrm{CH}_{3} \mathrm{CN}$ are principally emitted to the atmosphere by BB (70-85\% of total emissions for $\mathrm{HCN}$ and 90 $95 \%$ for $\mathrm{CH}_{3} \mathrm{CN}$; Li et al., 2003) and in contrast to $\mathrm{CO}$ have minimal anthropogenic sources. Ocean uptake and oxidation by $\mathrm{OH}$ are the primary and secondary loss mechanisms for both species (de Gouw et al., 2003; Li et al., 2003). CO, $\mathrm{HCN}$ and $\mathrm{CH}_{3} \mathrm{CN}$ all have atmospheric lifetimes of over a month (de Gouw et al., 2003; Li et al., 2003). It can therefore be assumed that these species are inert dispersive tracers for plumes intercepted when they are less than approximately a week old, since chemical losses over this period should be small. These lifetimes are also short enough so that BB emissions are a substantial increase over the ambient concentrations. For these reasons all three species are widely used tracers for BB (Hecobian et al., 2011; Hornbrook et al., 2011; Vay et al., 2011).

To allow comparison between species that were measured using different instruments with different response times a number of different data merges were used. When describing the bulk distribution encountered (Sect. 3) $10 \mathrm{~s}$ averaged measurements were employed, but when examining the individual BB case studies (Sect. 4) higher-resolution measurements of $3 \mathrm{~s}$ were applied. PTR-MS measurements were not used in the $3 \mathrm{~s}$ merge.

A common method to identify BB plumes is to use some combination of $\mathrm{HCN}, \mathrm{CH}_{3} \mathrm{CN}$ and $\mathrm{CO}$ to partition air masses between those that have, and those that have not, been 
recently influenced by biomass burning (Hornbrook et al., 2011; Vay et al., 2011; Palmer et al., 2013). A representative threshold concentration value and/or ratio is chosen from tracer-tracer relationships, where the tracer measurements above a certain threshold value are classified as a biomass burning plume. There are a variety of methods that can be used to choose the threshold, but no consistent method is used within the literature (Le Breton et al., 2013), as the chemical background to each dataset or region may be different, requiring unique and tailored analysis. The choice of threshold must also take account plume age, as typical plumes will continuously mix (dilute) with background air until they become indistinguishable from each other. For long-lived species, such as $\mathrm{CO}_{2}$ and $\mathrm{CH}_{4}, \mathrm{BB}$ will always make some contribution to their global mean background, further necessitating a tailored approach appropriate to the dataset under analysis.

To probe the history of the air masses encountered by the FAAM BAe-146 we used single-particle 3-dimensional (vertical motion enabled) back trajectories from the offline Hybrid Single-Particle Lagrangian Integrated Trajectory (HYSPLIT) model (Draxler and Rolph, 2003) with National Centers for Environmental Prediction (NCEP) reanalysis meteorological fields at $2.5^{\circ}$ spatial resolution on 17 levels. Fiveday back trajectories (with half-hourly outputs) were calculated with endpoints co-located with the aircraft position as reported by GPS at $60 \mathrm{~s}$ intervals along the aircraft flight track. This method allows us to qualitatively describe air mass history representative of the aircraft sampling. It should be noted that this method does not represent a source inversion and is used here to guide our analysis in terms of qualitative air mass history and general source regions.

The UK Met Office Numerical Atmospheric-dispersion Modelling Environment (NAME) (Jones et al., 2007) was used to complement the back trajectories generated using HYSPLIT. NAME is a stochastic Lagrangian particle dispersion model that can be run both forwards and backwards in time. NAME can use single site observations or 3-D meteorological data to drive the dispersion of the model particles. In this work we have used numerical weather prediction data from the UK Met Office Unified Model (Davies et al., 2005). These are operational analysis fields with a spatial resolution of $0.35^{\circ}$ longitude by $0.23^{\circ}$ latitude with 59 vertical levels (model top at $\sim 30 \mathrm{~km}$ ). NAME has previously been used to examine the dispersal of particulate matter originating from Russian agricultural fires and its impact on UK air quality (Witham and Manning, 2007). In this work we performed two sets of NAME simulations. The first simulations (not discussed further) were performed in order to simulate the dispersal of the biomass burning plumes that may have influenced our measurements. We focus here on the second set of simulations. These involved releasing 100000 particles/trajectories over a $1 \mathrm{~min}$ period from the locations (latitude, longitude, altitude, time) of a selected number of aircraft observations. The locations of the particles were tracked over a 5-day period going backwards in time. Our analysis focuses on the total column and surface ( 0 to $200 \mathrm{~m}$ a.g.l.) time-integrated latitude-longitude distribution of particles.

\section{Results and discussion}

\subsection{Large-scale distribution}

For the purpose of providing a useful dataset for wider climatological statistics, we present a broad summary of the BORTAS project using all sampled data, excluding the Atlantic transits to Halifax, to represent composition statistics consistent with boreal biomass burning that may be linked to satellite fire observations. The flights during the BORTAS experiment had the explicit aim of intercepting BB, and therefore the measurements discussed here do not represent a truly random sample of the atmosphere during this measurement period and will have a slight bias towards air masses that have been influenced by BB.

Observations on board the FAAM BAe-146 during the BORTAS flights are summarised in Fig. 2, and overall campaign statistics are shown in Table 1. Notable features of the $\mathrm{CO}_{2}$ altitude profile are the consistently depleted nearsurface concentrations, likely due to uptake by the biosphere. This hypothesis is supported by the enhancements in biogenic VOCs that generally occurred during periods of $\mathrm{CO}_{2}$ depletion. For example, at low altitudes $(<1000 \mathrm{~m})$ the mean concentration of isoprene $\left(\mathrm{C}_{5} \mathrm{H}_{8}\right)$, which is principally emitted to the atmosphere from terrestrial plants (Guenther et al., 2006), is a factor 6 larger for the lower $\mathrm{CO}_{2}$ quartile than it is for the higher $\mathrm{CO}_{2}$ quartile. In contrast to $\mathrm{CO}_{2}$, the nearsurface $\mathrm{CH}_{4}$ levels are in general enhanced by several tens of ppb compared to those aloft, suggesting significant localised and land-based sources in the region.

Pollution events are evident in Fig. 2c-d since $\mathrm{CO}$ and $\mathrm{CH}_{3} \mathrm{CN}$ have many high concentration outliers of an episodic or transitory nature that are many times larger than the cleaner conditions exhibited in the lower quartile. These extreme concentrations, largely associated with $\mathrm{BB}$, are relatively evenly distributed across all altitudes, showing that $\mathrm{BB}$ not only impacts the region surrounding the fire but is capable of causing changes in composition throughout the troposphere.

Clear evidence for enhancements due to $\mathrm{BB}$ can be found in the BORTAS $\mathrm{CO}_{2}$ and $\mathrm{CH}_{4}$ datasets. This is shown in Fig. 3, where the scatter plots have been colour-coded by $\mathrm{CH}_{3} \mathrm{CN}$ as a tracer for BB. However, these enhancements are proportionately quite small compared to their background levels and are obscured by variability in $\mathrm{CO}_{2}$ and $\mathrm{CH}_{4}$ that is not associated with changes in $\mathrm{CH}_{3} \mathrm{CN}$, suggesting that additional (possibly anthropogenic as well as biogenic) fluxes are influencing concentrations. As a consequence the correlation with $\mathrm{CO}$ across all flights is weak $\left(\mathrm{CO}_{2}: \mathrm{CO} R^{2}=0.09\right.$ and $\mathrm{CH}_{4}: \mathrm{CO} R^{2}=0.12$ ). This is in contrast to the majority 
Table 1. Statistics for all BORTAS flights excluding the transits from Cranfield, UK, to Nova Scotia, Canada, and the return journey.

\begin{tabular}{lrrrrrrr}
\hline & Mean & Median & Minimum & Maximum & PBL mean & BB plume mean & Background mean \\
\hline $\mathrm{CO}_{2}, \mathrm{ppm}$ & 384.8 & 385.1 & 371.5 & 397.1 & 381.3 & 385.8 & 383.8 \\
$\mathrm{CH}_{4}, \mathrm{ppb}$ & 1859 & 1857 & 1797 & 1968 & 1880 & 1859 & 1859 \\
\hline
\end{tabular}
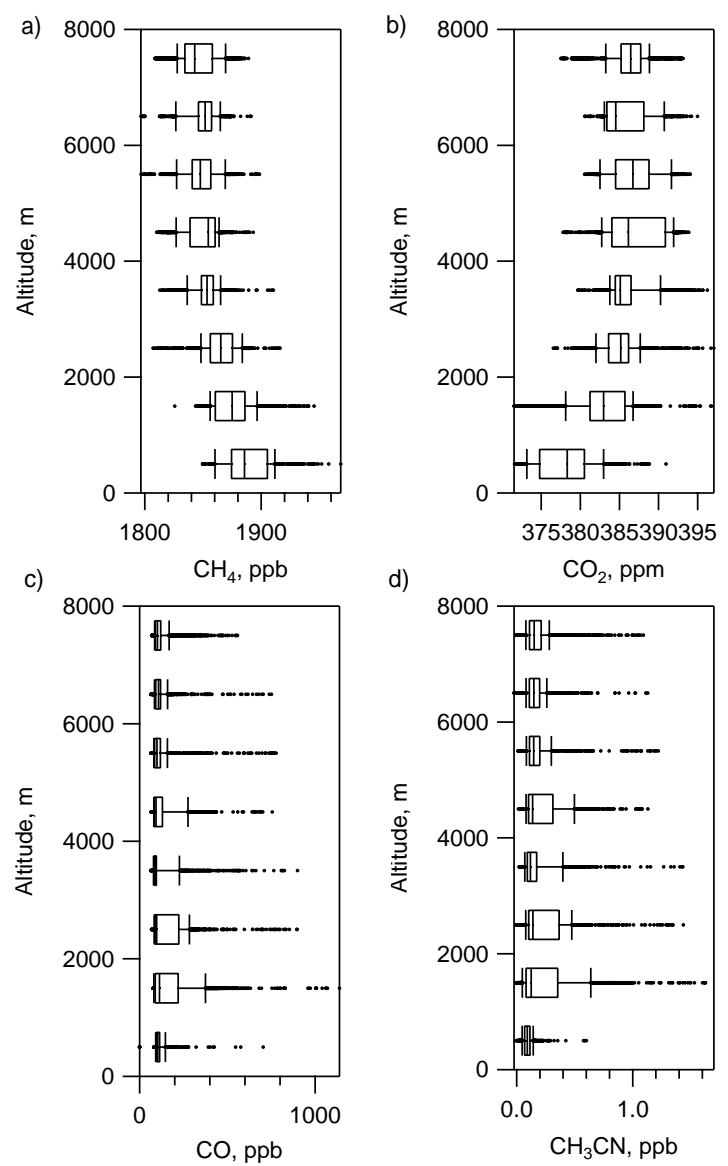

Fig. 2. A summary of the observations of $\mathrm{CH}_{4}, \mathrm{CO}_{2}, \mathrm{CO}$ and $\mathrm{CH}_{3} \mathrm{CN}$ made on the FAAM BAe-146 during the BORTAS project. The transits from Cranfield, UK, to Nova Scotia, Canada, and the return journey have been excluded from these plots. Boxes are 25 th and 75th percentiles, whiskers are 10th and 90th percentiles and the markers are outliers.

of VOCs, where the typical enhancements are several times larger than their background and the influence of $\mathrm{BB}$ on the dataset is much more distinct (Lewis et al., 2013).

To analyse the background measurements we filter the dataset for measurements made when the $\mathrm{HCN}$ and $\mathrm{CH}_{3} \mathrm{CN}$ concentrations are below the median for the campaign, $76 \mathrm{ppt}$ and $137 \mathrm{ppt}$, respectively. This will remove the influence of BB from all but the smallest and most well mixed plumes to give a confident background concentration. Using this criteria, the correlation between $\mathrm{CH}_{4}$ and $\mathrm{CO}_{2}$ is much stronger $\left(R^{2}=0.72\right)$, giving us good confidence in our a)

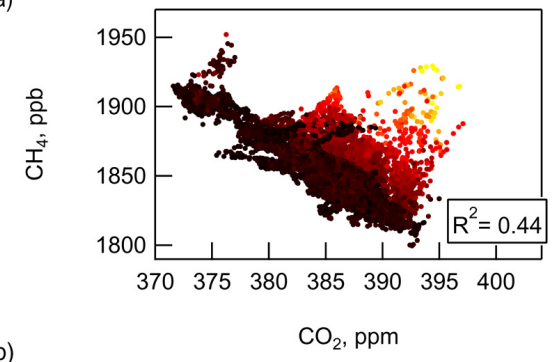

b)

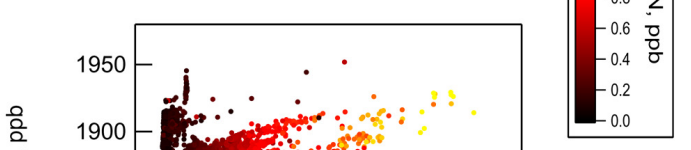

c)

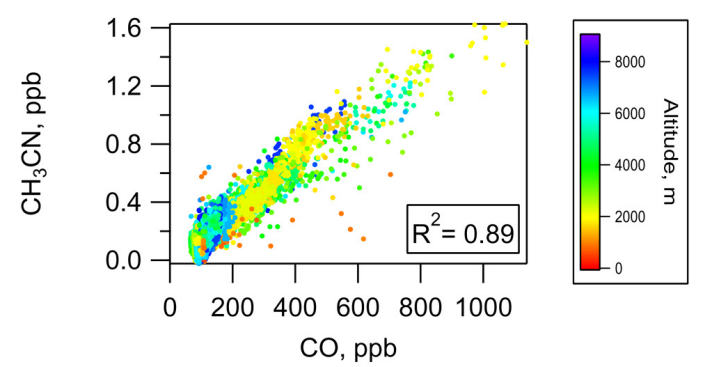

Fig. 3. The relationships between $\mathrm{CH}_{4}, \mathrm{CO}_{2}, \mathrm{CO}$ and $\mathrm{CH}_{3} \mathrm{CN}$ for the BORTAS flights with the exception of the Atlantic transits.

choice for the BORTAS dataset. A negative relationship is found with regression slope $(-5.31 \pm 0.01) \times 10^{-3} \mathrm{~mol} \mathrm{CH}_{4}$ $\left(\mathrm{molCO}_{2}\right)^{-1}$. A negative correlation is consistent with a combination of $\mathrm{CO}_{2}$ uptake by the biosphere within the region and surface emissions of $\mathrm{CH}_{4}$. Biogenic $\mathrm{CH}_{4}$-to- $\mathrm{CO}_{2}$ flux ratios have shown a wide degree of variability; for example ground-based eddy covariance flux measurements found the flux ratio to vary between -56 and $-2 \times 10^{-3} \mathrm{~mol} \mathrm{CH}_{4}$ $\left(\mathrm{mol} \mathrm{CO}_{2}\right)^{-1}$ from Californian rice fields over the growing season (McMillan et al., 2007).

Ethane $\left(\mathrm{C}_{2} \mathrm{H}_{6}\right)$ shares several common sources with $\mathrm{CH}_{4}$ : $\mathrm{BB}$, combustion of fossil fuels and biofuels; however it does not have a biogenic source. For this reason simultaneous measurement of $\mathrm{C}_{2} \mathrm{H}_{6}$ can aid the apportionment of $\mathrm{CH}_{4}$ sources (Simpson et al., 2012). Correlation between $\mathrm{C}_{2} \mathrm{H}_{6}$ 
and $\mathrm{CO}$ is much stronger than it is for $\mathrm{CH}_{4}\left(R^{2}=0.95\right.$ for all measurements; Lewis et al., 2013), whilst for both plume and non-plume measurements correlation between $\mathrm{C}_{2} \mathrm{H}_{6}$ and $\mathrm{CH}_{4}$ integrated across all flights during BORTAS is poor $\left(R^{2}<0.3\right)$. However, $\mathrm{C}_{2} \mathrm{H}_{6}: \mathrm{CH}_{4}$ correlation for background measurements was noted to range widely flight by flight, with a peak of 0.95 during flight B624 (for 8 samples) and a minimum of 0.05 for flight B622 (for 5 samples). This would suggest that the variability in non-fire (background) $\mathrm{CH}_{4}$ concentrations is generally due to biogenic emissions. However, it should be noted that the $\mathrm{C}_{2} \mathrm{H}_{6}$ observations were retrieved by analysing 529 flask samples, and therefore we do not have equivalent spatial or temporal resolution with the continuous in situ $\mathrm{CH}_{4}$ and $\mathrm{CO}$ measurements, nor the quantity of samples from which to fully investigate the relationship to $\mathrm{C}_{2} \mathrm{H}_{6}$ in the same way that we are able to do for the $0.1 \mathrm{~Hz}$ in situ measurements. Sample locations and times were manually chosen to reflect both plume and background air masses.

Examining bulk statistics for all science flight measurements, $\mathrm{CO}_{2}$ and $\mathrm{CH}_{4}$ concentrations made in $\mathrm{BB}$ plumes are only marginally different to those outside of plumes (Table 1). For $\mathrm{CO}_{2}$ the mean in-plume concentration is only 2 ppm higher than the mean out of plume, and within analytical uncertainty the mean $\mathrm{CH}_{4}$ concentrations are identical. In Sect. 4 we identify individual case studies in the dataset where enhancements due to BB can be quantified.

As reported by Palmer et al. (2013) fire activity during the BORTAS sampling period was dominated by widespread fires in northwestern Ontario. Extensive fires in this region took place from 17 to 19 July 2011, plumes from which were sampled over $1000 \mathrm{~km}$ downwind during measurement flights B621 to B624 (18 to 21 July 2011, Sect. 4.2). This region was also sampled in the near field (plumes $<1 \mathrm{~h}$ old) on 26 July 2011 (B626, Sect. 4.1); however, at this time, fire activity in the region was reduced and the plumes more localised. The flights later in the campaign (B628, 28 July 2011) sampled plumes that were reported to be over 7 days old (Parrington et al., 2013). Concentrations in these plumes were relatively low, with CO reaching $135 \mathrm{ppb}, \mathrm{HCN}$ $330 \mathrm{ppt}$ and $\mathrm{CH}_{3} \mathrm{CN} 310 \mathrm{ppt}$; nevertheless the correlation between $\mathrm{HCN}$ and $\mathrm{CO}\left(R^{2}=0.69\right.$ for the whole flight $)$ implies that they are still representative of a biomass burning origin.

As a tracer for incomplete combustion, $\mathrm{CO}$ enhancements are characteristic of not only BB but also anthropogenic activity. Throughout the BORTAS dataset regions of enhanced $\mathrm{CO}$ are almost entirely coincident with enhancements in $\mathrm{CH}_{3} \mathrm{CN}\left(R^{2}=0.89\right.$ for all measurements, Fig. 3), suggesting that anthropogenic emissions are well mixed and local sources had a minimal influence on the BORTAS dataset. An exception to this occurred during flight B629, which briefly overflew the Dartmouth Oil refinery located on Halifax Harbour, NS. Whilst overflying the refinery, $\mathrm{CO}_{2}$ was enhanced by $8 \mathrm{ppm}$ over the local average background and enhancements were also noted in $\mathrm{NO}_{\mathrm{x}}$ (NO up to $3.3 \mathrm{ppb}$ and $\mathrm{NO}_{2}$ up to $3.8 \mathrm{ppb}$ ). The high partitioning of $\mathrm{NO} / \mathrm{NO}_{2}$ suggests that this is a photochemically fresh plume and therefore local in origin. We note that there was no observable significant change in $\mathrm{CO}$ and $\mathrm{CH}_{4}$ or $\mathrm{BB}$ tracers (e.g. $\mathrm{CH}_{3} \mathrm{CN}$ ).

\subsection{Comparison with previous observations}

On Sable Island, approximately $100 \mathrm{~km}$ southeast of Halifax a WMO regional monitoring station makes long-term GHG observations. Given the different sampling domain, the BORTAS campaign statistics are comparable to the GHG measurements made on Sable Island (WDCGG, 2013). The mean $\mathrm{CO}_{2}$ concentration on Sable Island during the BORTAS sampling period was $386.5 \mathrm{ppm}, 1.7 \mathrm{ppm}$ higher than the BORTAS campaign mean and $5.2 \mathrm{ppm}$ higher than the BORTAS planetary boundary layer (PBL) mean (Sable Island $\mathrm{CO}_{2}$ statistics: median $=385.7 \mathrm{ppm}$ and inter-quartile range 384.2 to $388.5 \mathrm{ppm}$ ). The mean $\mathrm{CH}_{4}$ concentration on Sable Island of $1864 \mathrm{ppb}$ is $5 \mathrm{ppb}$ higher than the FAAM BAe-146 measurements and $15 \mathrm{ppb}$ lower than the BORTAS PBL mean (Sable Island $\mathrm{CH}_{4}$ statistics: median $=1860 \mathrm{ppb}$ and interquartile range 1856 to $1872 \mathrm{ppm}$ ).

Two previous airborne measurement campaigns have been performed within a sampling domain, altitude range and time of year similar to BORTAS. These are the 2008 ARCTAS experiment (Arctic Research of the Composition of the Troposphere from Aircraft and Satellites, described by Jacob et al., 2010) and the 1992 ABLE-3B experiment (Arctic Boundary Layer Expedition; Harriss et al., 1994). The airborne sampling portion of ARCTAS consisted of both spring and summer campaigns over much of the North American sub-Artic. During the summer deployment $\mathrm{CO}_{2}$ measurements had a mean of $382.8 \pm 3.0 \mathrm{ppm}$ and median $383.1 \mathrm{ppm}$, marginally lower than those during BORTAS. However, the ARCTAS project experienced a wider range of concentrations, 368.3 to $624.2 \mathrm{ppm}$. These very high concentrations were due to sampling intense boreal fires in the near field. Whilst median free-tropospheric $\mathrm{CO}_{2}$ values for each altitude bin range shown in Fig. 2 compare within several ppm to those observed during the ARCTAS summer deployment (Vay et al., 2011), BORTAS $\mathrm{CH}_{4}$ concentrations were also found to be generally similar to those during ARCTAS (Singh et al., 2010), as were other species such as $\mathrm{CO}$ and $\mathrm{O}_{3}$ (Parrington et al., 2013). Similar vertical $\mathrm{CH}_{4}$ gradients to those shown in Fig. 2 were observed during ABLE-3B. However, the baseline ABLE-3B $\mathrm{CH}_{4}$ concentrations are approximately $100 \mathrm{ppb}$ lower (Wofsy et al., 1994), reflecting the growth of global $\mathrm{CH}_{4}$ concentrations during the intervening $20 \mathrm{yr}$ period between the two projects (Dlugokencky et al., 2011).

\subsection{Comparison to MACC model composition}

To discuss trace gas measurements as recorded during BORTAS in the context of sources of composition model bias, we compared the in situ measurements of $\mathrm{CO}_{2}, \mathrm{CH}_{4}$ and $\mathrm{CO}$ on the FAAM BAe-146 to those from the Monitoring 
Atmospheric Composition and Change (MACC) project (Inness et al., 2013). The global MACC reanalysis service provides a reanalysis for the years 2003 to 2012 of trace gas and aerosol concentrations, with the reactive gases reanalysis system produced by the coupled Integrated Forecasting System-Model for OZone And Related chemical Tracers (IFS-MOZART) modelling and assimilation system. Benedictow et al. (2013) give the latest validation report on the MACC reanalysis product.

This comparison is shown in Fig. 4. The MACC fields used are statistics that have been determined over the corresponding BORTAS measurement period of 18 July to 21 July 2011 for the whole sample region covered by the FAAM BAe-146, excluding the Atlantic transits to and from Cranfield, UK (a geographic region of 40 to $60^{\circ} \mathrm{N}$ and 40 to $100^{\circ} \mathrm{W}$ ). Since the MACC fields have not been sampled at the exact time and position of the FAAM BAe-146 flights, precise agreement between measurement and model is not expected. However, the comparison is instructive since it tests the model's skill at simulating the large-scale features and typical background concentrations in the region. For comparison the in situ BORTAS dataset is binned using MACC product altitude levels. It should be pointed out that because of a known bias in the MACC reanalysis dataset for $\mathrm{CO}_{2}$, a different MACC product was used for $\mathrm{CO}_{2}$ in comparison to that used for $\mathrm{CO}$ and $\mathrm{CH}_{4}$. The $\mathrm{CO}_{2}$ fields were produced using a forward model that is run using optimized fluxes (see Chevallier et al., 2010). The two different products use slightly different pressure levels, which can be seen in Fig. 4, but this does not have an impact on the significance of the comparison as outlined below.

For CO, the MACC is able to reproduce both the high concentrations from episodic BB events and the approximate background levels with reasonable agreement to the measurements. Emission inventories augmented with MODIS (Moderate-Resolution Imaging Spectroradiometer) fire information, as well as CO observations from IASI and MOPITT, were assimilated during the reanalysis experiment. The mean difference between the medians for individual altitude bins is $\sim 5 \mathrm{ppb}$ (comparable to the total column bias) and the inter-quartile ranges generally agree. The large negative CO biases observed by Inness et al. (2013) are not seen here, possibly because that comparison found the largest discrepancies in the boundary layer at urban sites affected by pollution.

Similarly good agreement is seen for $\mathrm{CO}_{2}$ where the median concentrations for each altitude bin are typically within $1 \mathrm{ppm}$ and the inter-quartile ranges are comparable. MACC is also able to simulate the general structure of the $\mathrm{CH}_{4}$ altitude profile. However there exists a significant disagreement over the absolute concentrations; MACC typically underestimates $\mathrm{CH}_{4}$ by approximately $75 \mathrm{ppb}$. This deviation is sufficiently large and consistent in the vertical, such that it is unlikely to be a result of the BORTAS sampling strategy. Detailed analysis of this disparity is beyond the scope of this pa-
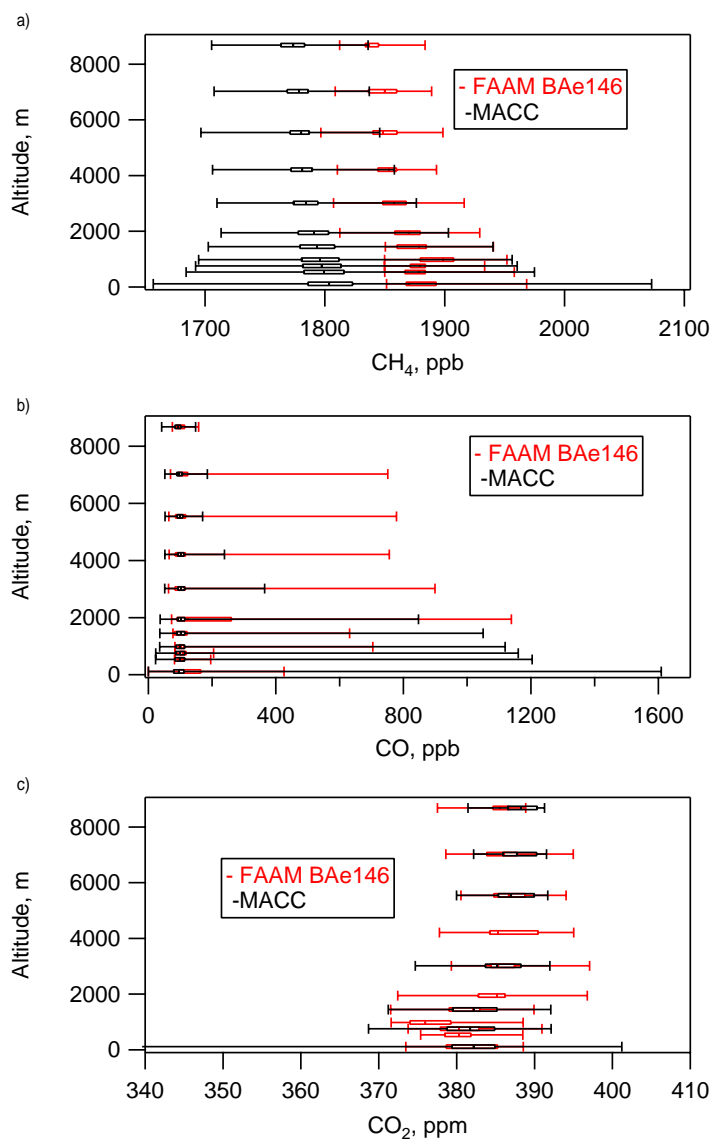

Fig. 4. Comparison between in situ measurements on the FAAM BAe-146 and those derived from the Monitoring Atmospheric Composition and Change (MACC) project over the BORTAS sampling domain and period. Boxes are the 25th and 75th percentiles, the whiskers are the maximum and minimum values.

per, but we note the $\mathrm{CH}_{4}$ reanalysis data use retrievals from the SCanning Imaging Absorption SpectroMeter for Atmospheric CHartographY (SCIAMACHY) on board the ENVISAT satellite, which have been produced by the Netherlands Institute for Space Research (SRON), and that these values are known to have a negative bias (A. Agusti-Panareda and S. Massart, personal communication, 2013)

\section{Enhancement ratios and emission factors}

Trace gas emissions from biomass burning are often expressed as either an emission ratio (ER) or an emission factor (EF). An ER for a species, X, is the number of molecules of this species emitted into the atmosphere per molecule of a tracer for biomass burning, usually $\mathrm{CO}_{2}$ or $\mathrm{CO}$. It is equal to the regression slope of the measurements of $\mathrm{X}$ in a plume vs. the simultaneous measurement of the tracer species. To calculate ERs we use an orthogonal distance regression, weighted by the measurement uncertainty. The uncertainties 
given are the standard deviation of the fit. Correlation coefficients $\left(R^{2}\right)$ have also been included, which have been calculated using least squares regression. ERs can also be calculated by first subtracting the background concentrations from the in the plume measurements. However we have chosen not to use this approach, due to the subjective nature of choosing a background. As a BB plume moves away from its source, chemical reactions may enhance or deplete a particular species and as a consequence the determined ER. For this reason, the ER for short-lived species should only be calculated using measurements in the freshest possible fire plumes. In aged plumes the regression slope is usually known as a normalised excess mixing ratio (NEMR) or enhancement ratio instead (Yokelson et al., 2009; Hecobian et al., 2011; Akagi et al., 2011, 2012; Le Breton et al., 2013; Yokelson et al., 2013).

While an EF is the mass of the species emitted for every $\mathrm{kg}$ of dry biomass burnt, it is usually calculated using the carbon mass balance technique (Andreae and Merlet, 2001; Christian et al., 2007; Simpson et al., 2011; Akagi et al., 2012). This is based on the assumption that all combusted carbon (C) is measured in the plume. The EF, in $\mathrm{g}$ of X per kg of dry matter burnt, can be calculated using Eq. (1):

$\mathrm{EF}=F_{\mathrm{C}} \cdot \frac{M_{\mathrm{X}} \Delta C_{\mathrm{X}}}{M_{\mathrm{C}} \Delta C_{\mathrm{T}}}$

where $F_{\mathrm{C}}$ is the fraction of $\mathrm{C}$ in the fuel. For boreal forests this is chosen to be $500 \mathrm{~g} \mathrm{~kg}^{-1}$ and is thought to be accurate to $\pm 10 \%(2 \sigma)$ (Susott et al., 1996; Yokelson et al., 1999). $M_{\mathrm{X}}$ and $M_{\mathrm{C}}$ are the molecular masses of species $\mathrm{X}$ and carbon $\left(12.011 \mathrm{~g} \mathrm{~mol}^{-1}\right)$, respectively. $\Delta C_{\mathrm{X}} / \Delta C_{\mathrm{T}}$ is the ratio of the number of moles of species $X$ to the total number of moles of carbon emitted by the fire. This can be calculated using the ER, when CO is used as a tracer, of $\mathrm{X}$ $\left(\Delta\left[C_{X}\right] / \Delta[C O]\right)$ and all the other $C$ containing molecules in the plume. It is not possible to measure all $\mathrm{C}$ containing molecules, so we approximate total $\mathrm{C}$ using only $\mathrm{CO}_{2}, \mathrm{CO}$ and $\mathrm{CH}_{4}$. This will result in an overestimate of the true value, but this is only expected to amount to a few percent. Simpson et al. (2011) measured $\mathrm{CO}_{2}, \mathrm{CO}, \mathrm{CH}_{4}$ and 80 non-methane VOCs in Canadian biomass burning plumes and found that $98.6 \%$ of the measured $\mathrm{C}$ was either in the form of $\mathrm{CO}_{2}, \mathrm{CO}$ or $\mathrm{CH}_{4}$. We can then calculate $\Delta C_{\mathrm{X}} / \Delta C_{\mathrm{T}}$ using Eq. (2):

$$
\frac{\Delta C_{\mathrm{X}}}{\Delta C_{\mathrm{T}}}=\frac{\frac{\Delta\left[\mathrm{C}_{\mathrm{X}}\right]}{\Delta[\mathrm{CO}]}}{1+\frac{\Delta\left[\mathrm{CO}_{2}\right]}{\Delta[\mathrm{CO}]}+\frac{\Delta\left[\mathrm{CH}_{4}\right]}{\Delta[\mathrm{CO}]}}
$$

An emission rate for a species can be estimated by combining its EF with an estimate of the total matter burnt e.g. using The Global Fire Emissions Database (van der Werf et al., 2010). However, a single EF is not sufficient to describe emissions within a particular biome or even an individual fire that will go through several distinct combustion phases with different EFs. A review of the variables that influence the EF is provided by van Leeuwen and van der Werf (2011).
These include factors related to the material burnt (size, density, water content, vegetation spacing) as well as meteorological factors (wind speed, humidity, precipitation, temperature). For this reason we include the modified combustion efficiency (MCE, Eq. 3) in Table 2 as a measure of whether a fire is predominantly in the flaming or smouldering phase.

$\mathrm{MCE}=\frac{1}{1-\frac{\Delta[\mathrm{CO}]}{\Delta\left[\mathrm{CO}_{2}\right]}}$

Laboratory studies suggest that this varies from 0.8 for purely smouldering combustion to 0.99 for purely flaming combustion (Yokelson et al., 1996).

\subsection{Near field biomass burning: 26 July 2011 plume}

The flights during the BORTAS project had the aim of sampling BB plumes that were a variety of ages. Only Flight B626 (26 July 2011) sampled fresh plumes ( $<1 \mathrm{~h}$ ). This flight consisted of a transit from Halifax, Nova Scotia, followed by a boundary layer survey over an active fire region in northwestern Ontario $\left(\sim 52.5^{\circ} \mathrm{N}, \sim 93.6^{\circ} \mathrm{W}\right)$, before landing at Thunder Bay, Ontario. We concentrate our analysis here on the low-level portion of the flight $(900 \mathrm{~m}$ to $1100 \mathrm{~m})$. Figure 5a shows a time series of BB tracer concentrations whilst repeatedly penetrating a number of plumes, where the BB tracers discussed in Sect. 2 were clearly elevated above their local background.

At such close proximity to the fires the plumes are of limited spatial extent (of the order $1 \mathrm{~km}$ ), it is therefore beneficial to use higher frequency measurements $(0.33 \mathrm{~Hz})$ for analysis rather than the $0.1 \mathrm{~Hz}$ measurements that have been used previously. We use the method described by LeBreton et al. (2013), using HCN and CO, to determine whether BB has recently influenced an air mass. Firstly, the HCN and CO time series are examined for periods out-of-plume during the low-level flying that represent a typical background. For CO and HCN this was facilitated by relatively large enhancements (up to factor 15) in the plume. The mean and standard deviation of the background regions were then determined. Measurements made when the simultaneous $\mathrm{CO}$ and $\mathrm{HCN}$ mole fraction were 6 standard deviations greater than their background were deemed to be in a BB plume. It should be noted that the measurements are not normally distributed (due to non-random sampling) and as a result no assumption should be made about the proportion of measurements within 1 standard deviation of the mean. The 6 standard deviation threshold is only used to represent a significant enhancement over the background.

For CO the background has a mean of $105 \mathrm{ppb}$ with a standard deviation of $9 \mathrm{ppb}$, while $\mathrm{HCN}$ had a mean of $259 \mathrm{ppt}$ with a standard deviation of $50 \mathrm{ppt}$. These CO concentrations are typical of the background levels encountered during both this project (Fig. 2) and previous measurements made in similar locations (Vay et al., 2011). Due to a lack of field measurements the distribution of 
Table 2. Emission ratios (ER), normalised excess mixing ratios (NEMR) and emission factors (EF) determined by sampling boreal biomass burning plumes over eastern Canada. MCE is the modified combustion efficiency, a measure of the combustion phase of the fire. The ER and EF determined in this study show good agreement with previous studies in boreal regions. Andreae and Merlet (2001) and Akagi et al. (2011) have compiled values from the literature for extra-tropical forests. Simpson et al. (2011) report values for forest fires in boreal Canada made as part of the ARCTAS project. Units are $\left(\mathrm{mol}(\mathrm{mol} \mathrm{CO})^{-1}\right)$ for the NEMR/ERs and $\mathrm{g}(\mathrm{kg} \text { dry matter })^{-1}$ for the EFs. Runs are when the aircraft does not change altitude and profiles are when there is a change in altitude.

\begin{tabular}{|c|c|c|c|c|c|c|c|c|}
\hline & \multirow[t]{2}{*}{ Flight } & \multirow[t]{2}{*}{ MCE } & \multicolumn{2}{|c|}{$\mathrm{CO}_{2}$} & \multicolumn{2}{|c|}{$\mathrm{CO}$} & \multicolumn{2}{|c|}{$\mathrm{CH}_{4}$} \\
\hline & & & ER/NEMR & $\mathrm{EF}$ & ER / NEMR & $\mathrm{EF}$ & ER / NEMR & $\mathrm{EF}$ \\
\hline Fresh plume & B626 & $0.83 \pm 0.01$ & $5.1 \pm 0.3$ & $1512 \pm 185$ & - & $189 \pm 23$ & $0.079 \pm 0.001$ & $8.5 \pm 0.9$ \\
\hline \multirow{11}{*}{ Aged plumes (> 1 day) } & B621 Run 3 & $0.90 \pm 0.01$ & $9.1 \pm 0.8$ & $1638 \pm 255$ & - & $114 \pm 17$ & $0.079 \pm 0.004$ & $5.2 \pm 0.7$ \\
\hline & B621 Run 15 & - & - & - & - & - & $0.109 \pm 0.003$ & - \\
\hline & B621 Profile 2 & $0.90 \pm 0.001$ & $9.4 \pm 0.2$ & $1648 \pm 169$ & - & $111 \pm 11$ & $0.05 \pm 0.001$ & $3.3 \pm 0.3$ \\
\hline & B621 Profile 3 & - & - & - & - & - & $0.16 \pm 0.01$ & - \\
\hline & B622 Run 1 & $0.89 \pm 0.01$ & $8.1 \pm 0.5$ & $1618 \pm 216$ & - & $126 \pm 17$ & $0.078 \pm 0.003$ & $5.7 \pm 0.7$ \\
\hline & B622 Run 3 & $0.93 \pm 0.01$ & $14.4 \pm 0.2$ & $1708 \pm 173$ & - & $75 \pm 8$ & $0.044 \pm 0.001$ & $1.8 \pm 0.2$ \\
\hline & B622 Run 6 & $0.92 \pm 0.04$ & $13 \pm 7$ & $1683 \pm 1400$ & - & $84 \pm 73$ & $0.12 \pm 0.04$ & $5.9 \pm 3.9$ \\
\hline & B622 Run 9 & $0.92 \pm 0.03$ & $12 \pm 5$ & $1679 \pm 1000$ & - & $87 \pm 53$ & $0.12 \pm 0.05$ & $6.1 \pm 1$ \\
\hline & B623 Run 1 and 2 & - & - & - & - & - & $0.133 \pm 0.001$ & - \\
\hline & B623 Run 3 & - & - & - & - & - & $0.093 \pm 0.001$ & - \\
\hline & B623 Run 5 and 6 & $0.93 \pm 0.001$ & $14.2 \pm 0.2$ & $1702 \pm 173$ & - & $76 \pm 8$ & $0.081 \pm 0.001$ & $3.5 \pm 0.4$ \\
\hline \multirow{3}{*}{ Literature values } & Andreae and Merlet (2001) & - & - & $1569 \pm 131$ & - & $107 \pm 37$ & - & $4.7 \pm 1.9$ \\
\hline & Simpson et al. (2011) & - & $9.1 \pm 5.8$ & $1616 \pm 180$ & - & $113 \pm 72$ & $0.072 \pm 0.044$ & $4.7 \pm 2.9$ \\
\hline & Akagi et al. (2011) & - & - & $1489 \pm 121$ & - & $127 \pm 45$ & - & $6.0 \pm 3.1$ \\
\hline
\end{tabular}

$\mathrm{HCN}$ in the troposphere is not as well known as it is for $\mathrm{CO}$. Mean tropospheric $\mathrm{HCN}$ concentrations from previous studies were found to be $243 \pm 118$ ppt (Singh et al., 2003) and $220 \mathrm{ppt}$ ( $\mathrm{Li}$ et al., 2003), comparable to the background that we determine. Tracer-tracer scatter analysis of $\mathrm{CO}_{2}, \mathrm{CH}_{4}$ and $\mathrm{CO}$ measurements are shown in Fig. 5b and c. For both $\mathrm{CO}_{2}$ and $\mathrm{CH}_{4}$, strongly correlated $\left(R^{2}=0.95\right.$ for $\mathrm{CH}_{4}$, and $R^{2}=0.69$ for $\left.\mathrm{CO}_{2}\right)$ linear relationships were found for the $\mathrm{BB}$ plume measurements as expected. Since the flight traversed across a small region several times, we include all BB plume measurements to calculate a single ER/EF per species for this period. ERs are found to be $0.079 \pm 0.001 \mathrm{molCH}_{4}(\mathrm{~mol} \mathrm{CO})^{-1}$ and $5.9 \pm 0.4 \mathrm{~mol} \mathrm{CO}_{2}(\mathrm{~mol} \mathrm{CO})^{-1}$. From these ERs, using Eq. (1) and Eq. (2), EFs of $8.5 \pm \dot{0} .9 \mathrm{~g}$ (kg dry matter $)^{-1}$ and $1512 \pm 185 \mathrm{~g}$ (kg dry matter) ${ }^{-1}$ can be calculated for $\mathrm{CH}_{4}$ and $\mathrm{CO}_{2}$, respectively. Calculated EFs are comparable with previous studies in boreal regions (see Table 2), as are those for $\mathrm{CO}$ and $\mathrm{HCN}$ (not shown).

An MCE of $0.83 \pm 0.01$ is characteristic of smouldering combustion, which would typically result in proportionally more reduced compounds being released. This will likely be the reason for a relatively large amount of $\mathrm{CH}_{4}$ being released compared to previous studies. van Leeuwen and van der Werf (2011) grouped $\mathrm{CH}_{4} \mathrm{EFs}$ in the literature based on biome and the fires' MCE. The EF calculated for B626 shows an excellent agreement with the amount of $\mathrm{CH}_{4}$ emitted for a fire with its combustion efficiency as predicted from their work.

To examine the sensitivity of the definition of a BB plume on the determined EFs, we repeated the analysis varying the threshold from 0 to 20 standard deviations above the background. For both $\mathrm{CH}_{4}$ and $\mathrm{CO}_{2}$ the correlation with $\mathrm{CO}$ increases as the threshold rises, as would be expected from removing non-BB sources from the dataset used in the EF calculation. The increase in correlation is more dramatic for $\mathrm{CO}_{2}$ than $\mathrm{CH}_{4}$ (for all thresholds the $\mathrm{CH}_{4}$ vs. $\mathrm{CO} R^{2}$ is always greater than 0.8). Apart from standard deviation thresholds less than 6 , the determined EFs are within $10 \%$ of each other, lending confidence in our choice of this threshold whilst simultaneously providing potential uncertainty that this compromise may impose. This highlights the importance of examining the sensitivity of the determined ER and EF to the method used to define a BB plume. A higher sensitivity is expected to be found when relatively few data points exist in a plume compared to those in background regions, as was the case for B626. We acknowledge this extra uncertainty and use a 6 standard deviation approach for calculating NEMR and EFs in aged plumes.

\subsection{Far-field biomass burning: 18 to 21 July 2011 plumes}

From 18 to 21 July 2011 four measurement flights took place (B621 to B624), during which a number of air masses were intercepted that had clearly been influenced by BB. Flight B621 (18 July 2011) travelled east from Halifax, NS, refuelling in Goose Bay, NL, before returning to Halifax, NS. On the outbound transit a significant plume was intercepted to the east of the Gulf of St Lawrence, between 4 and $7 \mathrm{~km}$. $\mathrm{CH}_{4}$ was raised by approximately $100 \mathrm{ppb}$ over the background and concentrations exceeded $1900 \mathrm{ppb}$, while HCN reached 

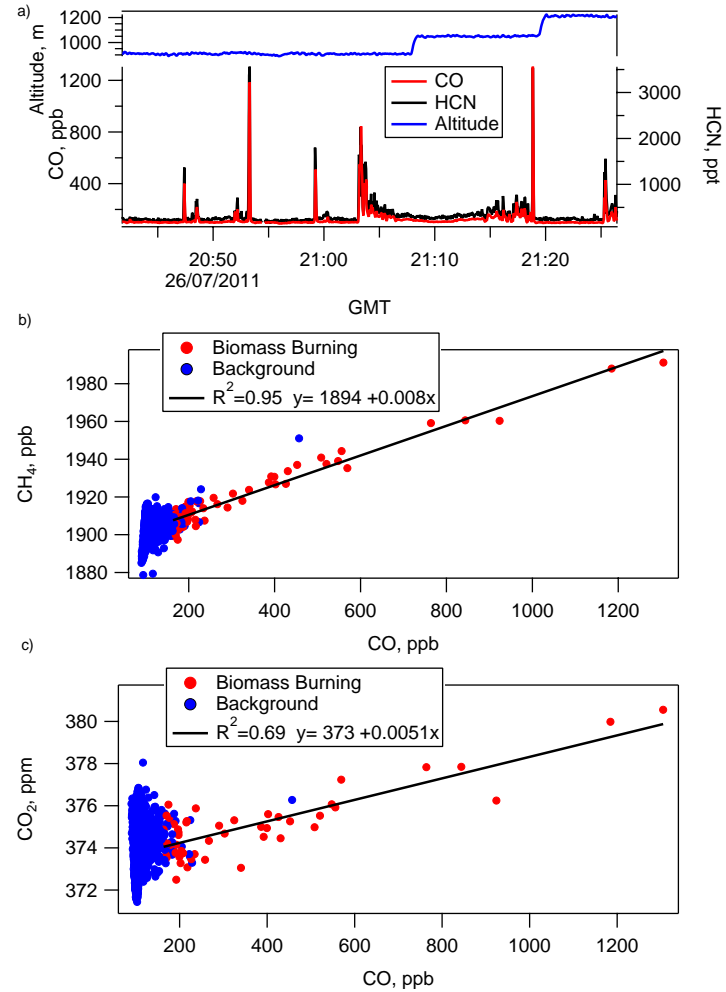

Fig. 5. (a) Time series of $\mathrm{CO}$ and $\mathrm{HCN}$ in fresh boreal biomass burning plumes measured by BORTAS flight B626 over northwestern Ontario. BB plumes were identified using simultaneous measurements of tracer species $\mathrm{CO}$ and $\mathrm{HCN}$ (the thresholds used were the periods during which $\mathrm{CO}$ and $\mathrm{HCN}$ were both 6 standard deviations greater than their local background). Strong linear relationships were found for both (b) $\mathrm{CH}_{4}$ and (c) $\mathrm{CO}_{2}$ with $\mathrm{CO}$ for measurements made within these plumes.

$4.5 \mathrm{ppb}$. Once the FAAM BAe-146 had descended through the $\mathrm{BB}$ plume, a trend of increasing $\mathrm{CH}_{4}$ and decreasing $\mathrm{CO}_{2}$ could be identified. $\mathrm{CO}$ and $\mathrm{HCN}$ remain relatively constant during this descent until another layer of $\mathrm{BB}$ is encountered at $2 \mathrm{~km}$.

Flights B622 and B623 both took place on the 20 July 2011; B622 travelled from Halifax to Quebec City, while B623 is the return journey (Fig. 1). Deep profiles and constant altitude runs were performed over southern Quebec and New Brunswick. Both CO and HCN showed a high degree of variability and were both elevated throughout much of the flights, over the altitude range 2000 to $8000 \mathrm{~m}$. Peak plume concentrations exceeded $1 \mathrm{ppm}$ and $1 \mathrm{ppb}$ for $\mathrm{CO}$ and $\mathrm{HCN}$, respectively.

HYSPLIT back trajectories suggest that the plumes encountered during B621 to B624 originated 2 to 4 days previously, from fires in western Ontario (Fig. 6). Figure 7b and $\mathrm{c}$ show how the trajectories were used to identify the source of the fire; Fig. 7b shows 5-day back trajectories with endpoints co-located with the FAAM BAe-146 for the en-
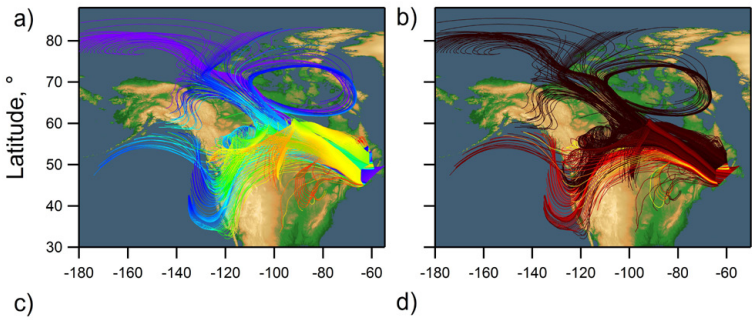

c)

d)
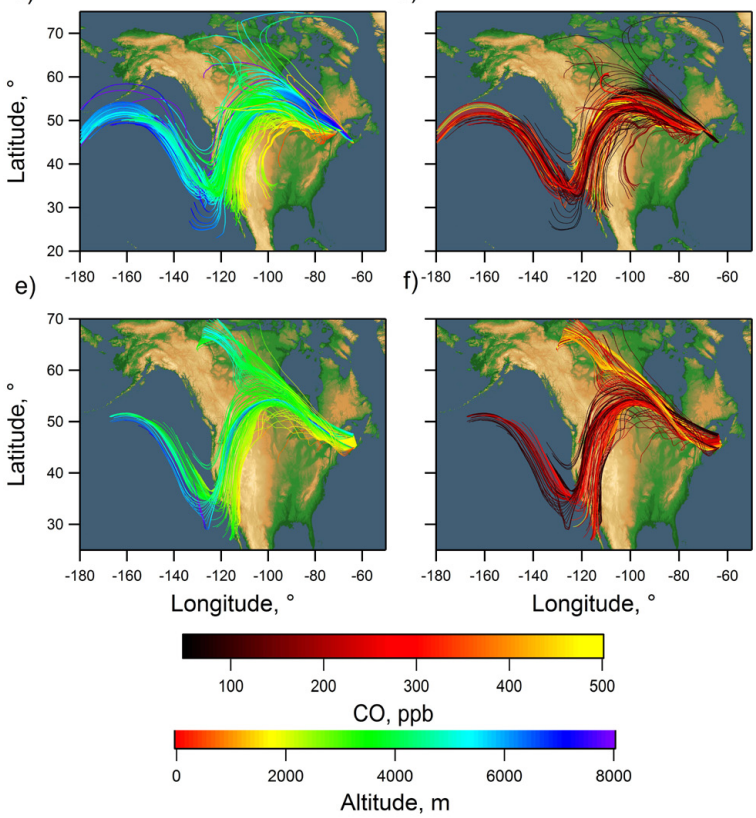

Fig. 6. Five-day HYSPLIT back trajectories whose endpoints colocate with every minute of the FAAM BAe-146 flight track, for the whole of the flights B621 (a, b), B622 (c, d) and B623 (e, f). Panels (a), (c) and (e) have been colour-coded by altitude, while (b), (d) and (f) have been colour-coded by the $\mathrm{CO}$ measurement on the FAAM BAe-146 at the endpoint of each trajectory.

tire flight. When the trajectories are selected that are associated with the enhanced $\mathrm{CO}$ and $\mathrm{HCN}$ (Fig. 7c), the majority overpass a region in northwestern Ontario that is identified as having had active fires as observed by MODIS. We acknowledge that HYSPLIT trajectories are not able to simulate the added buoyancy of a fire plume (pyroconvection); therefore the plume injection profile near to the fires is not known, and as a consequence these air masses may have potentially been influenced from further afield such as northern Alberta and the Northwest Territories, for B621 and B623 in particular (Fig. 6). However, Parrington et al. (2013) determined a similar age for these plumes by comparing ratios of VOCs to estimate the degree of photochemical processing that the plumes had experienced and hence an approximate age.

To investigate this further, we also examined dispersion model ensembles and surface footprints. NAME columnintegrated sensitivity plots are shown in Fig. 8. These show 

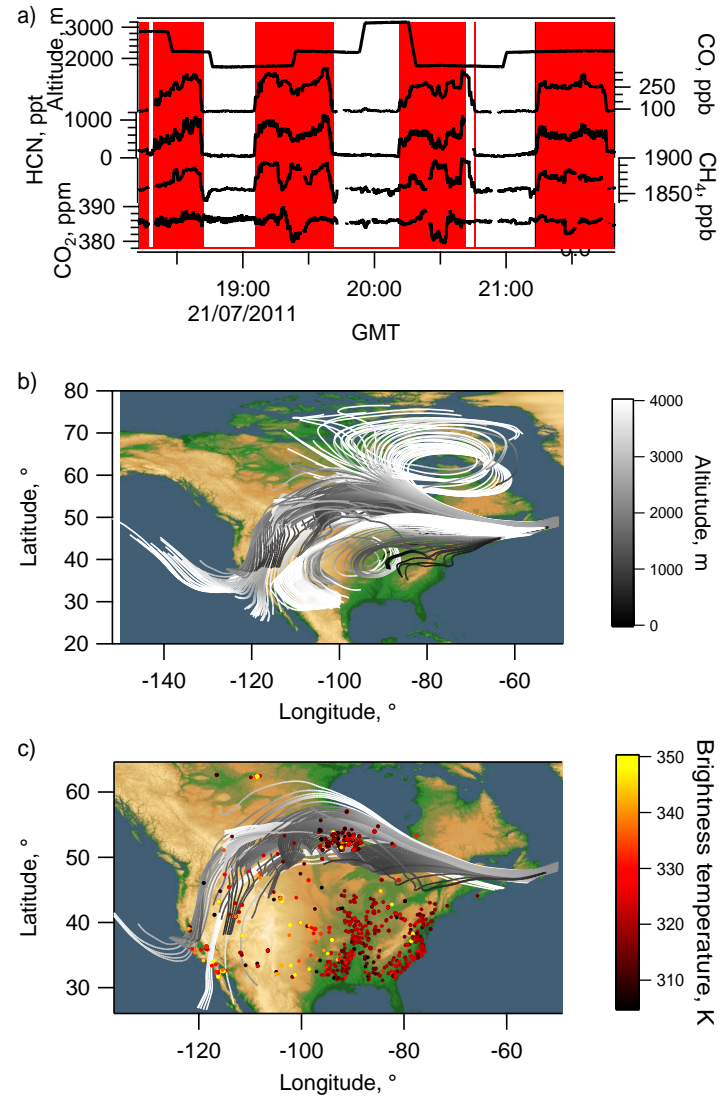

Fig. 7. (a) Time series whilst sampling a biomass burning plume near the coast of Newfoundland during flight B624. The red background indicates that the sampling was in a BB plume. (b) HYSPLIT 5-day back trajectories for the whole of flight B624. The trajectories were started at 60 s intervals along the flight starting point. (c) Only the back trajectories that end whilst flying in a biomass burning plume, as identified by the in situ $\mathrm{HCN}$ and $\mathrm{CO}$ measurements on the FAAM BAe-146. Markers are active fires detected by MODIS for the 5 days prior to the flight.

air masses that were associated with BB passed over the same fire region in northwestern Ontario as indicated by the HYSPLIT trajectories (Figs. 6 and 7). Column-integrated sensitivity plots, from NAME, for flights B622 and B623 are shown in Fig. 8. However, when examining only the surface footprint over the 5-day air mass history (see the bottom panels of Fig. 8), we see a mixed picture. For B622 (Fig. 8d), there is a footprint in close proximity to the fires detected by MODIS (relative sensitivity to northern Ontario fires $=1.9 \%$ ). However, for B623 (Fig. 8b), there is little evident surface contact over the 5-day history in regions with significant fire activity (relative sensitivity to northern Ontario fires $=0.1 \%$ ). This nicely illustrates the efficacy and pitfalls of air mass history analysis using Lagrangian trajectory and dispersion models run backwards in time. For B622, NAME guides us well in the surface attribution of BB sources, while for B623, if we were not otherwise expectant of dynamics such as active py-

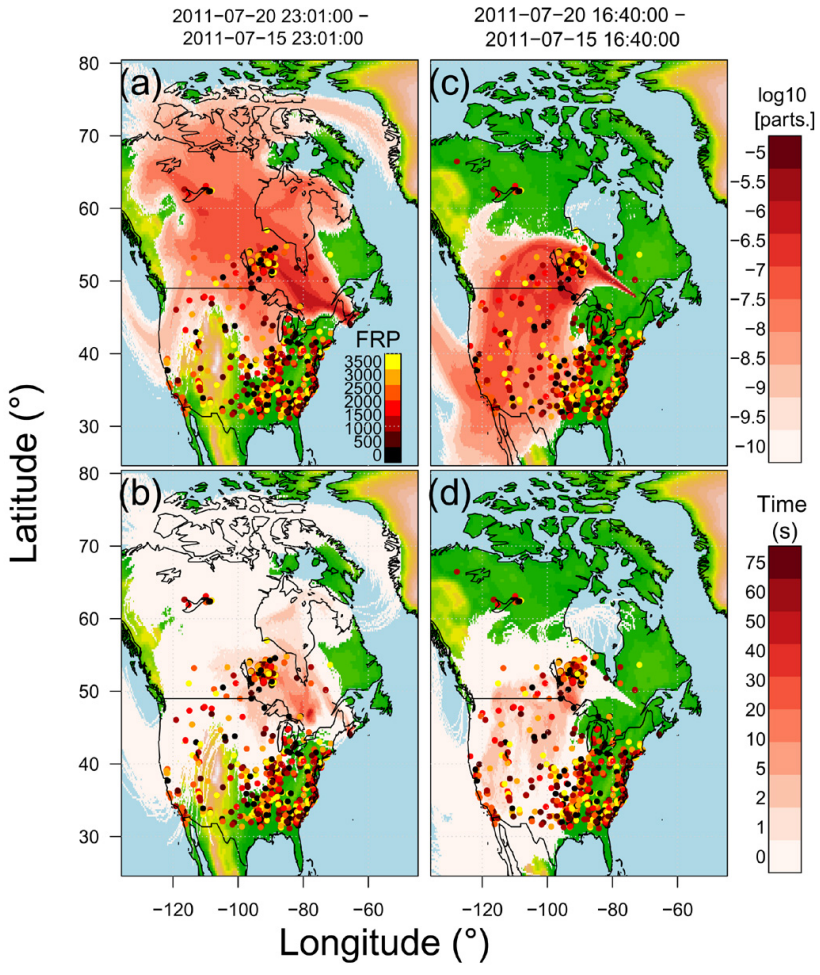

Fig. 8. NAME total column (a and c) and surface (b and d) sensitivity footprints for two BB plumes sampled during flight B623 (a and b) and B622 (c and d). Darker shading represents a greater sensitivity to that region. Markers are active fires detected by MODIS for the 5 days prior to the flight, and they are coloured by the fire radiative power (FRP).

roconvection (Gonzi and Palmer, 2010; Glatthor et al., 2013), then NAME would suggest a non-combustion surface source. The fact that all trajectories (both HYSPLIT and NAME) pass over the fire region is consistent with the injection of material into those higher-level trajectories by pyroconvenction, which is known to be active in the area. Without prior knowledge of the injection profile of material it is not possible to accurately model dispersion in the forward frame, yet these dynamical history fields from NAME and HYSPLIT together nicely illustrate the passage of air over the fire region.

Whilst aircraft in situ measurements are essential for giving highly accurate quantitative information about the background and plume concentrations, their limited spatial coverage means that it is often difficult to map the full extent and movement of the plume purely from these measurements. Satellite measurements, whilst limited in their sampling and vertical sensitivity, are able to inform on these large spatial scales. The Infrared Atmospheric Sounding Interferometer (IASI) is a nadir viewing instrument flying operationally on the MetOp-A satellite (Hilton et al., 2012). 

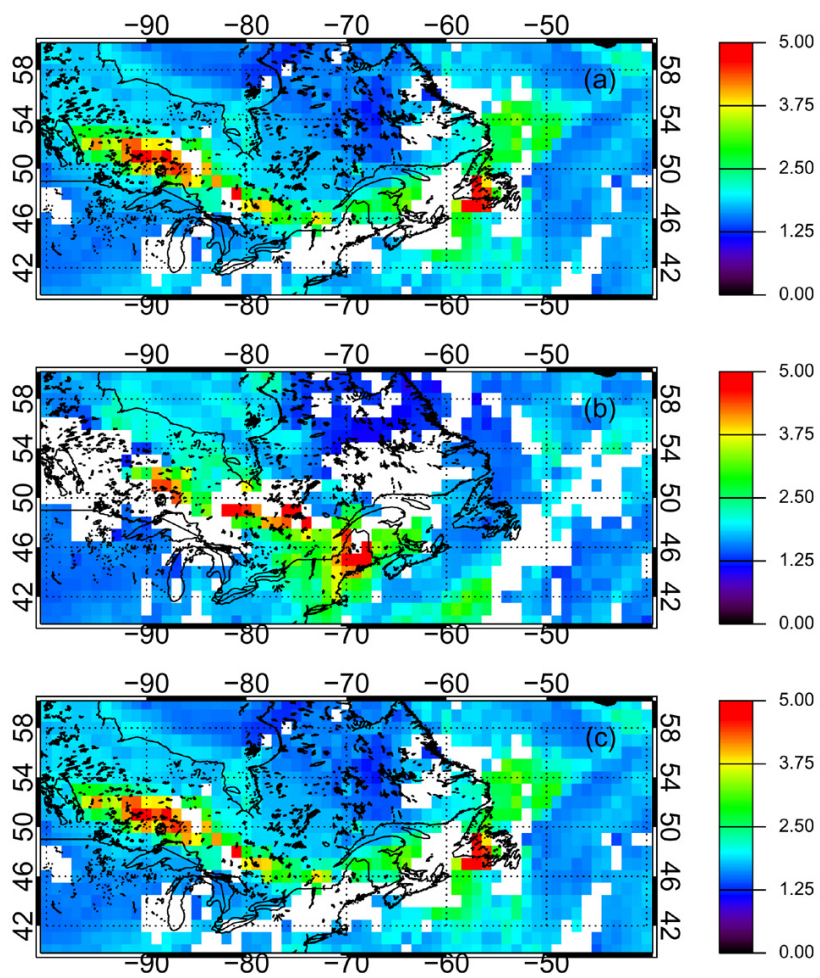

Fig. 9. The daytime mean total column $\mathrm{CO}\left(1 \times 10^{18} \mathrm{~mol} \mathrm{~cm}^{-2}\right)$ on a $1^{\circ}$ by $1^{\circ}$ grid from the Infrared Atmospheric Sounding Interferometer (IASI) on the MetOp-A satellite for the dates (a) 18 July 2011, (b) 20 July 2011 and (c) 21 July 2011.

IASI total column (TC) CO (daytime overpass) values, retrieved using the FORLI algorithm (Kerzenmacher et al., 2012) (Fig. 9), are visually compared here to the FAAM BAe-146 CO in situ concentrations, to provide further illustration that the enhanced concentrations of $\mathrm{CO}$ came from in-plume sampling. IASI shows enhancements in approximately the same location as those identified by the FAAM BAe-146. It is also able to show that the plume covers much of the eastern Canadian coast. The satellite measurements also support the suggestion that the plumes originated from fires in northwestern Ontario.

In theory, as long as the atmospheric lifetime of a species is significantly longer than the age of a plume, it should be possible to calculate ER using measurements in plumes that are several days old, since the calculated NEMR should be approximately equal to the ER at source. However, due to the strong vertical gradients in $\mathrm{CO}_{2}$ and $\mathrm{CH}_{4}$ (Fig. 2) that were observed over Canada, further consideration needs to made before NEMRs can be calculated for plumes that have been lofted out of the boundary layer into the free troposphere. When a plume is sampled at several altitudes it can be expected that it may have mixed with background air with composition reflecting different origins. As a result when the profile is examined as a whole, strong correlation between two pyrogenic species may not be observed and the uncertainty in the calculation of a NEMR would be large. This lack of correlation may also be due to several different ERs at source that mix during transport to the receptor site.

When the individual flights were analysed as a whole correlations between $\mathrm{CO}, \mathrm{CH}_{4}$ and $\mathrm{CO}_{2}$ were in general weak $\left(R^{2}<0.4\right)$. This was still the case when filters for $\mathrm{BB}$ were applied using $\mathrm{HCN}$ or $\mathrm{CH}_{3} \mathrm{CN}$. For this reason, it is necessary to partition the flights into individual constant altitude runs or vertical profiles to calculate NEMRs. In general, correlation was found to be more robust when the individual runs are examined separately. Table 2 shows NEMRs for all runs and profiles when the correlation coefficient $\left(R^{2}\right)$ is greater than 0.60 . Where possible EFs are also calculated assuming no chemical loss during transport.

The calculated $\mathrm{CH}_{4}$ EFs range between $1.8 \pm 0.2$ and

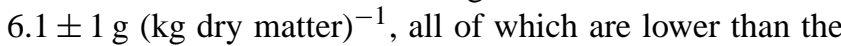
$8.5 \mathrm{~g}$ (kg dry matter $)^{-1}$ that was determined when the northwestern Ontario fires were sampled in the near field. However, as mentioned in Sect. 3.1, the aged plumes originated from a period of younger fires and more intense activity. Such fires would typically have a higher MCE (Wooster et al., 2011), which is representative of a larger proportion of flaming combustion and therefore a lower proportion of reduced compounds, such as $\mathrm{CH}_{4}$. This highlights the difficulty in calculating budgets for $\mathrm{BB}$, since fires in one region with approximately the same vegetation type can have such a range of EFs.

For all $\mathrm{CH}_{4} \mathrm{EFs}$ we find a regression slope of EF $=-47 \times \mathrm{MCE}+47 \quad\left(R^{2}=0.54\right)$. A similar relationship was found by several previous studies, such as Yokelson et al. (2008) for fires in a tropical forest (EF $\left.=-47 \times \mathrm{MCE}+49, R^{2}=0.72\right)$, Yokelson et al. (2003) for savanna fires $\left(\mathrm{EF}=-49 \times \mathrm{MCE}+48, R^{2}=0.86\right)$ and Korontzi et al. (2003) also for savannah fires $(E F=$ $\left.-48 \times \mathrm{MCE}+47, R^{2}=0.88\right)$. However, van Leeuwen and van der Werf (2011), who synthesised literature values, found a steeper relationship for extra-tropical forests $(\mathrm{EF}=$ $-59.992 \times \mathrm{MCE}+60.967)$ though with weaker correlation $\left(R^{2}=0.27\right)$.

However, uncertainties are larger when calculating ER/EF from measurements in aged plumes; an example of this occurred during flight number B624 (21 July 2012). Near the coast of Newfoundland a large biomass burning plume was sampled between $\sim 2$ and $3 \mathrm{~km}$ altitude. Runs were repeatedly performed into and out of the same plume at different altitudes (Fig. 1). Figure 7a shows a measurement time series of several trace gas concentrations during these runs. $\mathrm{CO}$ and HCN both show a clear enhancement consistent with a $\mathrm{BB}$ plume and there is excellent correlation between the two tracers $\left(R^{2}=0.94\right.$, Fig. 10a). The HCN to CO NEMR for this plume was found to be $(3.03 \pm 0.02) \times 10^{-3} \mathrm{~mol} \mathrm{HCN}$ $(\mathrm{mol} \mathrm{CO})^{-1}$. This NEMR is in reasonable agreement with the ratio when sampling BB in the near field both in this study and in previous studies (Simpson et al., 2011). Similarly 


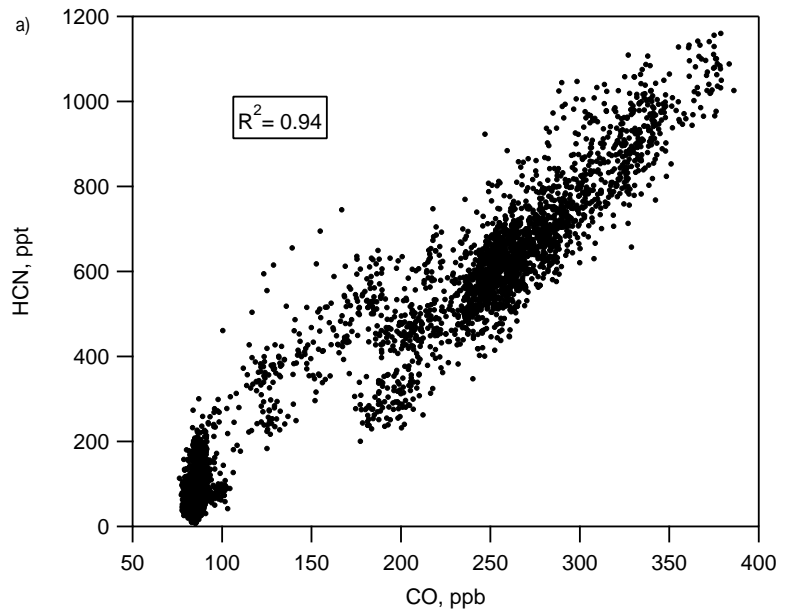

b)

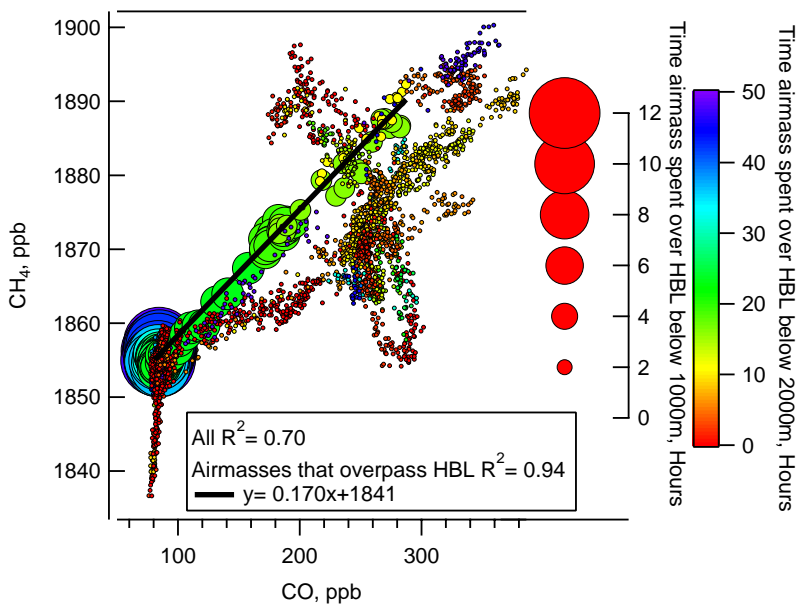

Fig. 10. Tracer-tracer relationships for a BB plume sampled during flight B624. Plot (b), showing the relationship between $\mathrm{CH}_{4}$ and $\mathrm{CO}$, has been colour-coded and sized according to the length of time the HYSPLIT trajectories spent over wetlands near Hudson Bay (HBL).

strong agreement is seen for hydrocarbons such as $\mathrm{C}_{2} \mathrm{H}_{6}$ $\left(R^{2}=0.97\right)$ and $\mathrm{C}_{3} \mathrm{H}_{8}$ (Propane, $\left.R^{2}=0.88\right)$.

The BB plume is not as clearly defined in the $\mathrm{CH}_{4}$ and $\mathrm{CO}_{2}$ time series as it is for the other species associated with biomass burning. This is expected to be partly due to their proportionately higher mean background relative to their typical enhancement and also because there are additional non$\mathrm{BB}$ sources and sinks of these gases relative to $\mathrm{CO}$ and $\mathrm{HCN}$ (e.g. biospheric uptake and wetland biogenic emission). Correlation between $\mathrm{CO}_{2}$ and $\mathrm{CO}$ is very weak $\left(R^{2}=0.03\right)$. This suggests that the majority of the $\mathrm{BB} \mathrm{CO}_{2}$ signal for this plume has been removed during transport due to a combination of biospheric uptake and mixing with other air masses.

However, even though the correlation between $\mathrm{CH}_{4}$ and CO is still strong $\left(R^{2}=0.70\right)$, a single mixing line cannot be identified in the scatter plot with CO (Fig. 10b) when using the threshold criterion used in the near-field analysis earlier. This suggests that there may have been mixing into the plume by a localised source during trajectory from fire source to sampling location. Back trajectories illustrate this diversity. We see that during the flight a variety of air masses were sampled, including some that had recently descended from the free troposphere $(>4 \mathrm{~km})$ over the Arctic in the polar jetstream. As expected, these air masses are associated with the lowest amounts of CO, typically less than $100 \mathrm{ppb}$. Other trajectories have originated from the southern US.

The trajectories suggest that since being emitted the plume has travelled over central Canada before being sampled. During this time it is likely that the plume will have mixed with air masses containing enhanced $\mathrm{CH}_{4}$ from biogenic emissions associated with the Canadian wetlands, e.g. the Hudson Bay Lowlands (HBL). This is well known to be a significant source of $\mathrm{CH}_{4}$ and is thought to comprise approximately $10 \%$ of the global boreal wetland emissions of $\mathrm{CH}_{4}$, or about 2.3 Tg per year (Pickett-Heaps et al., 2011). To investigate this further we define the HBL as the geographic region 50 $60^{\circ} \mathrm{N}, 75-96^{\circ} \mathrm{W}$. Figure $10 \mathrm{~b}$ colour-codes the scatter plot according to the length of time that the trajectories spent in this region below $2000 \mathrm{~m}$, and the markers have also been sized depending on the length of time the trajectories spent within this region below $1000 \mathrm{~m}$. The longer an air mass spends at low altitude within this region, the more sensitive it will be to HBL as a source of $\mathrm{CH}_{4}$. An NEMR of $0.170 \pm 0.003$ ( $R^{2}=0.97$ ) can be calculated for just those air masses that have passed over HBL below $1000 \mathrm{~m}$. Though not unrealistic, this is larger than typically measured for BB, suggesting that the enhancement may not be purely due to BB. As a general point, we report NEMRs for aged plumes with the important caveat that the impacts (and therefore uncertainty) of mixing cannot be quantified using the available dataset. This is an important consideration for existing and future datasets of this type where far-field NEMRs have been calculated and careful analysis of multiple tracers and air mass history must always accompany any such attempt.

A clear region where $\mathrm{CH}_{4}$ is anti-correlated with both $\mathrm{CO}_{2}$ $\left(R^{2}=0.74\right)$ and $\mathrm{CO}\left(R^{2}=0.55\right)$ can be identified (Fig. 10b), with enhancement ratios of $(-3.79 \pm 0.04) \times 10^{-3} \mathrm{~mol} \mathrm{CH}_{4}$ $\left(\mathrm{mol} \mathrm{CO}_{2}\right)^{-1}$ and $-0.284 \pm 0.003 \mathrm{~mol} \mathrm{CH}_{4}(\mathrm{~mol} \mathrm{CO})^{-1}$. This could suggest mixing or advection of an aged fire plume into a region of an enhanced $\mathrm{CH}_{4}$ surface flux (e.g. biogenic emission of $\mathrm{CH}_{4}$ over wetlands as noted in the trajectory analysis for this flight earlier). However, this additional mixing renders this particular air mass (represented by the anti-correlated mixing line in Fig. 10b) invalid for calculation of a subsequent NEMR. We note the existence of this air mass here for purposes of completeness and by way of advice when working with aged plumes that may have been influenced along their trajectory. Careful analysis and selection of data must be performed to remove sources of bias such as this in NEMR calculation of plumes which are otherwise still viable as representative of BB. Several previous studies have identified this phenomena whereby mixing in a $\mathrm{BB}$ plume 
results in the calculated NEMR plume no longer being representative of the fire ER (Mauzerall et al., 1998; Crounse et al., 2009; Yokelson et al., 2013).

\section{Conclusions}

Airborne in situ measurements of $\mathrm{CO}_{2}, \mathrm{CH}_{4}$ and other trace gases were made over eastern Canada, using the FAAM BAe-146 research aircraft, as part of the BORTAS experiment. Both $\mathrm{CO}_{2}$ and $\mathrm{CH}_{4}$ showed a wide degree of variability, which ranged 371.5 to $397.1 \mathrm{ppm}$ for $\mathrm{CO}_{2}$, and 1797 to $1968 \mathrm{ppb}$ for $\mathrm{CH}_{4}$, representing the unique nature of the various fire plumes sampled. Vertical concentration profiles were found to be broadly comparable with previous measurements, such as those from the ARCTAS project and reanalysed composition fields, that assimilate IASI/MOPITT satellite measurements, from the European Union funded MACC project. Source-specific tracers were used to distinguish between air masses. $\mathrm{CO}_{2}$ extrema were characterised by $\mathrm{BB}$ emissions and biospheric uptake, while $\mathrm{CH}_{4}$ concentrations were dominated by both $\mathrm{BB}$ and biogenic emissions.

BB plumes were sampled throughout the troposphere over an altitude range of $\sim 900 \mathrm{~m}$ to $\sim 8000 \mathrm{~m}$. Nearfield sampling of fires in northwestern Ontario yielded EFs of $1512 \pm 185 \mathrm{~g}(\mathrm{~kg} \text { dry matter })^{-1}$ and $8.5 \pm 0.9 \mathrm{~g}$ (kg dry matter) ${ }^{-1}$ for $\mathrm{CO}_{2}$ and $\mathrm{CH}_{4}$, respectively. Using a combination of in situ HCN measurements, Lagrangian trajectory models and MODIS active fire maps, it was found that plumes from this region were sampled several thousand kilometres downwind when they were 2 to 4 days old. It was found that significant uncertainties exist when calculating EF/ERs from measurements in aged plumes due to the mixing that can occur with non-fire sources during transport such as biogenic emissions in this case and that special care must be taken when interpreting far-field data of this type in both existing and future BB datasets. In these aged plumes, EFs were found to vary between $1618 \pm 216$ and $1702 \pm 173 \mathrm{~g}$ (kg dry matter) ${ }^{-1}$ of $\mathrm{CO}_{2}$ and $1.8 \pm 0.2$ and $6.1 \pm 1 \mathrm{~g} \mathrm{(kg} \mathrm{dry} \mathrm{matter)}{ }^{-1}$ of $\mathrm{CH}_{4}$. In summary, the results from this study provide a novel set of fire emission factors and climatological statistics that will inform modelling and process-related studies in the Canadian boreal region.

Acknowledgements. The authors wish to thank all those involved in the BORTAS project. Airborne data were obtained using the FAAM BAe-146 Atmospheric Research Aircraft (ARA) operated by Directflight Ltd (DFL) and managed by the Facility for Airborne Atmospheric Measurements (FAAM), which is a joint entity of the Natural Environment Research Council (NERC) and the UK Meteorological Office. MACC Data provided by the MACC-II project, funded by the European Union under the 7th Framework Programme. The authors would like to thank A. Agusti-Panareda and S. Massart (ECMWF) for advice about the use of the MACC dataset. IASI CO data provided by LATMOS/CNRS \& ULB. The authors are grateful to Doug Worthy (Environment Canada) for providing $\mathrm{CO}_{2}$ and $\mathrm{CH}_{4}$ data from the Sable Island monitoring station. The ABLE 3B 10 s merges were obtained from the NASA Global Tropospheric Experiment data archive at the LaRC DACC. S. J. O'Shea is in receipt of a NERC PhD studentship. This research was supported by the Natural Environment Research Council under grant number NE/F017391/1.

Edited by: S. Matthiesen

\section{References}

Akagi, S. K., Yokelson, R. J., Wiedinmyer, C., Alvarado, M. J., Reid, J. S., Karl, T., Crounse, J. D., and Wennberg, P. O.: Emission factors for open and domestic biomass burning for use in atmospheric models, Atmos. Chem. Phys., 11, 4039-4072, doi:10.5194/acp-11-4039-2011, 2011.

Akagi, S. K., Craven, J. S., Taylor, J. W., McMeeking, G. R., Yokelson, R. J., Burling, I. R., Urbanski, S. P., Wold, C. E., Seinfeld, J. H., Coe, H., Alvarado, M. J., and Weise, D. R.: Evolution of trace gases and particles emitted by a chaparral fire in California, Atmos. Chem. Phys., 12, 1397-1421, doi:10.5194/acp-12-13972012, 2012.

Andreae, M. O., and Merlet, P.: Emission of trace gases and aerosols from biomass burning, Global Biogeochem. Cy., 15, 955-966, doi:10.1029/2000gb001382, 2001.

Benedictow, A., Blechschmidt, A.-M., Bouarar, I., Cuevas, E., Clark, H., Flentje, H., Griesfeller, J., Huijnen, V., Huneeus, N., Jones, L., Kapsomenakis, J., Kinne, S., Lefever, K., Razinger, M., Richter, A., Schulz, M., Thomas, W., Thouret, V., Vrekoussis, M., Wagner, A., and Zerefos, C.: The MACC reanalysis: An 8-year data set of atmospheric composition, MACC-II Deliverable D_83.4, http://www.gmes-atmosphere.eu/documents/ maccii/deliverables/val/ (last access: 22 May 2013), 2013.

Cammas, J.-P., Brioude, J., Chaboureau, J.-P., Duron, J., Mari, C., Mascart, P., Nédélec, P., Smit, H., Pätz, H.-W., Volz-Thomas, A., Stohl, A., and Fromm, M.: Injection in the lower stratosphere of biomass fire emissions followed by long-range transport: a MOZAIC case study, Atmos. Chem. Phys., 9, 5829-5846, doi:10.5194/acp-9-5829-2009, 2009.

Chevallier, F., Ciais, P., Conway, T. J., Aalto, T., Anderson, B. E., Bousquet, P., Brunke, E. G., Ciattaglia, L., Esaki, Y., Frohlich, M., Gomez, A., Gomez-Palaez, A. J., Haszpra, L., Krummel, P. B., Langenfelds, R., Leuenberger, M., Machida, T., Maignan, F., Matsueda, H., Morgui, J. A., Mukai, H., Nakazawa, T., Peylin, P., Ramonet, M., Rivier, L., Sawa, Y., Schmidt, M., Steele, P., Vay, S. A., Vermeulen, A. T., Wofsy, S. C., and Worthy, D.: $\mathrm{CO}_{2}$ surface fluxes at grid point scale estimated from a global 21-year reanalysis of atmospheric measurements, J. Geophys. Res., 115, D21307, doi:10.1029/2010JD013887, 2010.

Christian, T. J., Yokelson, R. J., Carvalho, J. A., Jr., Griffith, D. W. T., Alvarado, E. C., Santos, J. C., Neto, T. G. S., Gurgel Veras, C. A., and Hao, W. M.: The tropical forest and fire emissions experiment: Trace gases emitted by smoldering logs and dung from deforestation and pasture fires in Brazil, J. Geophys. Res.Atmos., 112, D18308, doi:10.1029/2006jd008147, 2007.

Crounse, J. D., DeCarlo, P. F., Blake, D. R., Emmons, L. K., Campos, T. L., Apel, E. C., Clarke, A. D., Weinheimer, A. J., McCabe, D. C., Yokelson, R. J., Jimenez, J. L., and Wennberg, P. O.: Biomass burning and urban air pollution over the Cen- 
tral Mexican Plateau, Atmos. Chem. Phys., 9, 4929-4944, doi:10.5194/acp-9-4929-2009, 2009.

Crutzen, P. J., Heidt, L. E., Krasnec, J. P., Pollock, W. H., and Seiler, W.: Biomass burning as a source of atmospheric gases $\mathrm{CO}, \mathrm{H}_{2}, \mathrm{~N}_{2} \mathrm{O}, \mathrm{NO}, \mathrm{CH}_{3} \mathrm{CL}$ and $\mathrm{COS}$, Nature, 282, 253-256, doi:10.1038/282253a0, 1979.

Damoah, R., Spichtinger, N., Forster, C., James, P., Mattis, I., Wandinger, U., Beirle, S., Wagner, T., and Stohl, A.: Around the world in 17 days - hemispheric-scale transport of forest fire smoke from Russia in May 2003, Atmos. Chem. Phys., 4, 13111321, doi:10.5194/acp-4-1311-2004, 2004.

Damoah, R., Spichtinger, N., Servranckx, R., Fromm, M., Eloranta, E. W., Razenkov, I. A., James, P., Shulski, M., Forster, C., and Stohl, A.: A case study of pyro-convection using transport model and remote sensing data, Atmos. Chem. Phys., 6, 173185, doi:10.5194/acp-6-173-2006, 2006.

Davies, T., Cullen, M. J. P., Malcolm, A. J., Mawson, M. H., Staniforth, A., White, A. A., and Wood, N.: A new dynamical core for the Met Office's global and regional modeling of the atmosphere, Q. J. Roy. Meteorol. Soc., 608, 1759-1782, 2005.

de Gouw, J. A., Warneke, C., Parrish, D. D., Holloway, J. S., Trainer, M., and Fehsenfeld, F. C.: Emission sources and ocean uptake of acetonitrile $\left(\mathrm{CH}_{3} \mathrm{CN}\right)$ in the atmosphere, J. Geophys. Res.Atmos., 108, 4329, doi:10.1029/2002jd002897, 2003.

Dlugokencky, E. J., Walter, B. P., Masarie, K. A., Lang, P. M., and Kasischke, E. S.: Measurements of an anomalous global methane increase during 1998, Geophys. Res. Lett., 28, 499-502, doi:10.1029/2000g1012119, 2001.

Dlugokencky, E. J., Nisbet, E. G., Fisher, R., and Lowry, D.: Global atmospheric methane: budget, changes and dangers, P. T. R. Soc. A, 369, 2058-2072, doi:10.1098/rsta.2010.0341, 2011.

Draxler, R. R. and Rolph, G. D.: HYSPLIT (HYbrid Single-Particle Lagrangian Integrated Trajectory) Model, NOAA Air Resources Laboratory, Silver Spring, MD, USA, 2003.

Forster, P. and Ramaswamy, V.: Changes in Atmospheric Constituents and in Radiative Forcing, Climate Change 2007: the Physical Science Basis, Cambridge Univ. Press, Cambridge, UK, 129-234, 2007.

Gerbig, C., Schmitgen, S., Kley, D., Volz-Thomas, A., Dewey, K., and Haaks, D.: An improved fast-response vacuum-UV resonance fluorescence CO instrument, J. Geophys. Res.-Atmos., 104, 1699-1704, doi:10.1029/1998jd100031, 1999.

Gillett, N. P., Weaver, A. J., Zwiers, F. W., and Flannigan, M. D.: Detecting the effect of climate change on Canadian forest fires, Geophys. Res. Lett., 31, L18211, doi:10.1029/2004g1020876, 2004.

Glatthor, N., Höpfner, M., Semeniuk, K., Lupu, A., Palmer, P. I., McConnell, J. C., Kaminski, J. W., von Clarmann, T., Stiller, G. P., Funke, B., Kellmann, S., Linden, A., and Wiegele, A.: The Australian bushfires of February 2009: MIPAS observations and GEM-AQ model results, Atmos. Chem. Phys., 13, 1637-1658, doi:10.5194/acp-13-1637-2013, 2013.

Gonzi, S. and P. I. Palmer.: Vertical transport of surface fire emissions observed from space, J. Geophys. Res., 115, D02306, doi:10.1029/2009JD012053, 2010.

Guenther, A., Karl, T., Harley, P., Wiedinmyer, C., Palmer, P. I., and Geron, C.: Estimates of global terrestrial isoprene emissions using MEGAN (Model of Emissions of Gases and Aerosols from
Nature), Atmos. Chem. Phys., 6, 3181-3210, doi:10.5194/acp-63181-2006, 2006.

Harriss, R. C., Wofsy, S. C., Hoell Jr., J. M., Bendura, R. J., Drewry, J. W., McNeal, R. J., Pierce, D., Rabine, V., and Snell, R. L.: The arctic boundary layer expedition (ABLE 3B): July-August 1990, J. Geophys. Res., 99, 1635-1643, 1994.

Hecobian, A., Liu, Z., Hennigan, C. J., Huey, L. G., Jimenez, J. L., Cubison, M. J., Vay, S., Diskin, G. S., Sachse, G. W., Wisthaler, A., Mikoviny, T., Weinheimer, A. J., Liao, J., Knapp, D. J., Wennberg, P. O., Kürten, A., Crounse, J. D., Clair, J. St., Wang, Y., and Weber, R. J.: Comparison of chemical characteristics of 495 biomass burning plumes intercepted by the NASA DC-8 aircraft during the ARCTAS/CARB-2008 field campaign, Atmos. Chem. Phys., 11, 13325-13337, doi:10.5194/acp-1113325-2011, 2011.

Hilton, F., Armante, R., August, T., Barnet, C., Bouchard, A., Camy-Peyret, C., Capelle, V., Clarisse, L., Clerbaux, C., Coheur, P.-., Collard, A., Crevoisier, C., Dufour, G., Edwards, D., Faijan, F., Fourrié, N., Gambacorta, A., Goldberg, M., Guidard, V., Hurtmans, D., Illingworth, S., Jacquinet-Husson, N., Kerzenmacher, T., Klaes, D., Lavanant, L., Masiello, G., Matricardi, M., McNally, A., Newman, S., Pavelin, E., Payan, S., Péquignot, E., Peyridieu, S., Phulpin, T., Remedios, J., Schlüssel, P., Serio, C., Strow, L., Stubenrauch, C., Taylor, J., Tobin, D., Wolf, W. \& Zhou, D.: Hyperspectral earth observation from IASI, B. Am. Meteorol. Soc., 93, 347-370, 2012.

Hornbrook, R. S., Blake, D. R., Diskin, G. S., Fried, A., Fuelberg, H. E., Meinardi, S., Mikoviny, T., Richter, D., Sachse, G. W., Vay, S. A., Walega, J., Weibring, P., Weinheimer, A. J., Wiedinmyer, C., Wisthaler, A., Hills, A., Riemer, D. D., and Apel, E. C.: Observations of nonmethane organic compounds during ARCTAS - Part 1: Biomass burning emissions and plume enhancements, Atmos. Chem. Phys., 11, 11103-11130, doi:10.5194/acp11-11103-2011, 2011.

Inness, A., Baier, F., Benedetti, A., Bouarar, I., Chabrillat, S., Clark, H., Clerbaux, C., Coheur, P., Engelen, R. J., Errera, Q., Flemming, J., George, M., Granier, C., Hadji-Lazaro, J., Huijnen, V., Hurtmans, D., Jones, L., Kaiser, J. W., Kapsomenakis, J., Lefever, K., Leitão, J., Razinger, M., Richter, A., Schultz, M. G., Simmons, A. J., Suttie, M., Stein, O., Thépaut, J.-N., Thouret, V., Vrekoussis, M., Zerefos, C., and the MACC team: The MACC reanalysis: an 8 yr data set of atmospheric composition, Atmos. Chem. Phys., 13, 4073-4109, doi:10.5194/acp-13-4073-2013, 2013.

Jacob, D. J., Crawford, J. H., Maring, H., Clarke, A. D., Dibb, J. E., Emmons, L. K., Ferrare, R. A., Hostetler, C. A., Russell, P. B., Singh, H. B., Thompson, A. M., Shaw, G. E., McCauley, E., Pederson, J. R., and Fisher, J. A.: The Arctic Research of the Composition of the Troposphere from Aircraft and Satellites (ARCTAS) mission: design, execution, and first results, Atmos. Chem. Phys., 10, 5191-5212, doi:10.5194/acp-10-5191-2010, 2010.

Jaffe, D. A. and Wigder, N. L.: Ozone production from wildfires: A critical review, Atmos. Environ., 51, 1-10, doi:10.1016/j.atmosenv.2011.11.063, 2012.

Jaffe, D. A., Bertschi, I., Jaegle, L., Novelli, P., Reid, J. S., Tanimoto, H., Vingarzan, R., and Westphal, D. L.: Long-range transport of Siberian biomass burning emissions and impact on surface ozone in western North America, Geophys. Res. Lett., 31, L16106, doi:10.1029/2004g1020093, 2004. 
Jones, A. R., Thomson, D. J., Hort, M., and Devenish, B.: The U.K. Met Office's next-generation atmospheric dispersion model, NAME III, in: Air Pollution Modeling and its Application XVII (Proceedings of the 27th NATO/CCMS International Technical Meeting on Air Pollution Modelling and its Application), edited by: C., Borrego, and A.-L., Norman, Springer, 580-589, 2007.

Kerzenmacher, T., Dils, B., Kumps, N., Blumenstock, T., Clerbaux, C., Coheur, P.-F., Demoulin, P., García, O., George, M., Griffith, D. W. T., Hase, F., Hadji-Lazaro, J., Hurtmans, D., Jones, N., Mahieu, E., Notholt, J., Paton-Walsh, C., Raffalski, U., Ridder, T., Schneider, M., Servais, C., and De Mazière, M.: Validation of IASI FORLI carbon monoxide retrievals using FTIR data from NDACC, Atmos. Meas. Tech., 5, 2751-2761, doi:10.5194/amt5-2751-2012, 2012.

Korontzi, S., Ward, D. E., Susott, R. A., Yokelson, R. J., Justice, C. O., Hobbs, P. V., Smithwick, E. A. H., and Hao, W. M.: Seasonal variation and ecosystem dependence of emission factors for selected trace gases and PM2.5 for southern African savanna fires, J. Geophys. Res., 108, 4758, doi:10.1029/2003JD003730, 2003.

Langenfelds, R. L., Francey, R. J., Pak, B. C., Steele, L. P., Lloyd, J., Trudinger, C. M., and Allison, C. E.: Interannual growth rate variations of atmospheric $\mathrm{CO}_{2}$ and its $\delta^{13} \mathrm{C}, \mathrm{H}_{2}, \mathrm{CH}_{4}$, and $\mathrm{CO}$ between 1992 and 1999 linked to biomass burning, Global Biogeochem. Cy., 16, 1048, doi:10.1029/2001gb001466, 2002.

Le Breton, M., Bacak, A., Muller, J. B. A., O'Shea, S. J., Xiao, P., Ashfold, M. N. R., Cooke, M. C., Batt, R., Shallcross, D. E., Oram, D. E., Forster, G., Bauguitte, S. J.-B., Palmer, P. I., Parrington, M., Lewis, A. C., Lee, J. D., and Percival, C. J.: Airborne hydrogen cyanide measurements using a chemical ionisation mass spectrometer for the plume identification of biomass burning forest fires, Atmos. Chem. Phys., 13, 92179232, doi:10.5194/acp-13-9217-2013, 2013.

Lewis, A. C., Evans, M. J., Hopkins, J. R., Punjabi, S., Read, K. A., Purvis, R. M., Andrews, S. J., Moller, S. J., Carpenter, L. J., Lee, J. D., Rickard, A. R., Palmer, P. I., and Parrington, M.: The influence of biomass burning on the global distribution of selected non-methane organic compounds, Atmos. Chem. Phys., 13, 851-867, doi:10.5194/acp-13-851-2013, 2013.

Li, Q. B., Jacob, D. J., Yantosca, R. M., Heald, C. L., Singh, H. B., Koike, M., Zhao, Y. J., Sachse, G. W., and Streets, D. G.: A global three-dimensional model analysis of the atmospheric budgets of $\mathrm{HCN}$ and $\mathrm{CH}_{3} \mathrm{CN}$ : Constraints from aircraft and ground measurements, J. Geophys. Res.-Atmos., 108, 8827, doi:10.1029/2002jd003075, 2003.

Marquis, M. and Tans, P.: Climate change - Carbon crucible, Science, 320, 460-461, doi:10.1126/science.1156451, 2008.

Mauzerall, D. L., Logan, J. A., Jacob, D. J., Anderson, B. E., Blake, D. R., Bradshaw, J. D., Heikes, B., Sachse, G. W. , Singh, H., and Talbot, B.: Photochemistry in biomass burning plumes and implications for tropospheric ozone over the tropical South Atlantic, J. Geophys. Res., 103, 8401-8423, doi:10.1029/97JD02612, 1998.

McMillan, A. M. S., Goulden, M. L., and Tyler, S. C.: Stoichiometry of $\mathrm{CH}_{4}$ and $\mathrm{CO}_{2}$ flux in a California rice paddy, J. Geophys. Res.-Biogeo., 112, G01008, doi:10.1029/2006jg000198, 2007.

Monks, P. S., Granier, C., Fuzzi, S., Stohl, A., Williams, M. L., Akimoto, H., Amann, M., Baklanov, A., Baltensperger, U., Bey, I., Blake, N., Blake, R. S., Carslaw, K., Cooper, O. R., Dentener, F., Fowler, D., Fragkou, E., Frost, G. J., Generoso, S., Ginoux, P., Grewe, V., Guenther, A., Hansson, H. C., Henne, S., Hjorth,
J., Hofzumahaus, A., Huntrieser, H., Isaksen, I. S. A., Jenkin, M. E., Kaiser, J., Kanakidou, M., Klimont, Z., Kulmala, M., Laj, P., Lawrence, M. G., Lee, J. D., Liousse, C., Maione, M., McFiggans, G., Metzger, A., Mieville, A., Moussiopoulos, N., Orlando, J. J., O'Dowd, C. D., Palmer, P. I., Parrish, D. D., Petzold, A., Platt, U., Poeschl, U., Prevot, A. S. H., Reeves, C. E., Reimann, S., Rudich, Y., Sellegri, K., Steinbrecher, R., Simpson, D., ten Brink, H., Theloke, J., van der Werf, G. R., Vautard, R., Vestreng, V., Vlachokostas, C., and von Glasow, R.: Atmospheric composition change -global and regional air quality, Atmos. Environ., 43, 5268-5350, doi:10.1016/j.atmosenv.2009.08.021, 2009.

Murphy, J. G., Oram, D. E., and Reeves, C. E.: Measurements of volatile organic compounds over West Africa, Atmos. Chem. Phys., 10, 5281-5294, doi:10.5194/acp-10-5281-2010, 2010.

O'Shea, S. J., Bauguitte, S. J.-B., Gallagher, M. W., Lowry, D., and Percival, C. J.: Development of a cavity-enhanced absorption spectrometer for airborne measurements of $\mathrm{CH}_{4}$ and $\mathrm{CO}_{2}$, Atmos. Meas. Tech., 6, 1095-1109, doi:10.5194/amt-6-1095-2013, 2013.

Palmer, P. I., Parrington, M., Lee, J. D., Lewis, A. C., Rickard, A. R., Bernath, P. F., Duck, T. J., Waugh, D. L., Tarasick, D. W., Andrews, S., Aruffo, E., Bailey, L. J., Barrett, E., Bauguitte, S. J.-B., Curry, K. R., Di Carlo, P., Chisholm, L., Dan, L., Forster, G., Franklin, J. E., Gibson, M. D., Griffin, D., Helmig, D., Hopkins, J. R., Hopper, J. T., Jenkin, M. E., Kindred, D., Kliever, J., Le Breton, M., Matthiesen, S., Maurice, M., Moller, S., Moore, D. P., Oram, D. E., O'Shea, S. J., Owen, R. C., Pagniello, C. M. L. S., Pawson, S., Percival, C. J., Pierce, J. R., Punjabi, S., Purvis, R. M., Remedios, J. J., Rotermund, K. M., Sakamoto, K. M., da Silva, A. M., Strawbridge, K. B., Strong, K., Taylor, J., Trigwell, R., Tereszchuk, K. A., Walker, K. A., Weaver, D., Whaley, C., and Young, J. C.: Quantifying the impact of BOReal forest fires on Tropospheric oxidants over the Atlantic using Aircraft and Satellites (BORTAS) experiment: design, execution and science overview, Atmos. Chem. Phys., 13, 6239-6261, doi:10.5194/acp-13-6239-2013, 2013.

Parrington, M., Palmer, P. I., Lewis, A. C., Lee, J. D., Rickard, A. R., Di Carlo, P., Taylor, J. W., Hopkins, J. R., Punjabi, S., Oram, D. E., Forster, G., Aruffo, E., Moller, S. J., Bauguitte, S. J.-B., Allan, J. D., Coe, H., and Leigh, R. J.: Ozone photochemistry in boreal biomass burning plumes, Atmos. Chem. Phys., 13, 73217341, doi:10.5194/acp-13-7321-2013, 2013.

Pickett-Heaps, C. A., Jacob, D. J., Wecht, K. J., Kort, E. A., Wofsy, S. C., Diskin, G. S., Worthy, D. E. J., Kaplan, J. O., Bey, I., and Drevet, J.: Magnitude and seasonality of wetland methane emissions from the Hudson Bay Lowlands (Canada), Atmos. Chem. Phys., 11, 3773-3779, doi:10.5194/acp-11-3773-2011, 2011.

Seiler, W. and Crutzen, P. J.: Estimates of gross and net fluxes of carbon between the biosphere and the atmosphere from biomass burning, Clim. Chang., 2, 207-247, doi:10.1007/bf00137988, 1980.

Simpson, I. J., Rowland, F. S., Meinardi, S., and Blake, D. R.: Influence of biomass burning during recent fluctuations in the slow growth of global tropospheric methane, Geophys. Res. Lett., 33, L22808, doi:10.1029/2006g1027330, 2006.

Simpson, I. J., Akagi, S. K., Barletta, B., Blake, N. J., Choi, Y., Diskin, G. S., Fried, A., Fuelberg, H. E., Meinardi, S., Rowland, F. S., Vay, S. A., Weinheimer, A. J., Wennberg, P. O., Wiebring, P., Wisthaler, A., Yang, M., Yokelson, R. J., and Blake, D. R.: 
Boreal forest fire emissions in fresh Canadian smoke plumes: $\mathrm{C}_{1}-\mathrm{C}_{10}$ volatile organic compounds (VOCs), $\mathrm{CO}_{2}, \mathrm{CO}, \mathrm{NO}_{2}$, NO, HCN and CH3CN, Atmos. Chem. Phys., 11, 6445-6463, doi:10.5194/acp-11-6445-2011, 2011.

Simpson, I. J., Sulbaek Andersen, M. P., Meinardi, S., Bruhwiler, L., Blake, N. J., Helmig, D., Rowland, F. S., and Blake, D. R.: Long-term decline of global atmospheric ethane concentrations and implications for methane, Nature, 488, 490-494, doi:10.1038/nature11342, 2012.

Singh, H. B., Salas, L., Herlth, D., Kolyer, R., Czech, E., Viezee, W., Li, Q., Jacob, D. J., Blake, D., Sachse, G., Harward, C. N., Fuelberg, H., Kiley, C. M., Zhao, Y., and Kondo, Y.: In situ measurements of $\mathrm{HCN}$ and $\mathrm{CH}_{3} \mathrm{CN}$ over the Pacific Ocean: Sources, sinks, and budgets, J. Geophys. Res.-Atmos., 108, 8795, doi:10.1029/2002jd003006, 2003.

Singh, H. B., Anderson, B. E., Brune, W. H., Cai, C., Cohen, R. C., Crawford, J. H., Cubison, M. J., Czech, E. P., Emmons, L., Fuelberg, H. E., Huey, G., Jacob, D. J., Jimenez, J. L., Kaduwela, A., Kondo, Y., Mao, J., Olson, J. R., Sachse, G. W., Vay, S. A., Weinheimer, A., Wennberg, P. O., Wisthaler, A., and the ARCTAS Science Team.: Pollution influences on atmospheric composition and chemistry at high northern latitudes: Boreal and California forest fire emissions, Atmos. Environ., 44, 4553-4564, doi:10.1016/j.atmosenv.2010.08.026, 2010.

Susott, R. A., Olbu, G. J., Baker, S. P., Ward, D. E., Kauffman, J. B., and Shea, R.: Carbon, hydrogen, nitrogen, and thermogravimetric analysis of tropical ecosystem biomass, in: Biomass Burning and Global Change, edited by: Levine, J. S., MIT Press, Cambridge, 350-360, 1996.

van der Werf, G. R., Randerson, J. T., Giglio, L., Collatz, G. J., Mu, M., Kasibhatla, P. S., Morton, D. C., DeFries, R. S., Jin, Y., and van Leeuwen, T. T.: Global fire emissions and the contribution of deforestation, savanna, forest, agricultural, and peat fires (19972009), Atmos. Chem. Phys., 10, 11707-11735, doi:10.5194/acp10-11707-2010, 2010.

van Leeuwen, T. T. and van der Werf, G. R.: Spatial and temporal variability in the ratio of trace gases emitted from biomass burning, Atmos. Chem. Phys., 11, 3611-3629, doi:10.5194/acp11-3611-2011, 2011.

Vay, S. A., Choi, Y., Vadrevu, K. P., Blake, D. R., Tyler, S. C., Wisthaler, A., Hecobian, A., Kondo, Y., Diskin, G. S., Sachse, G. W., Woo, J. H., Weinheimer, A. J., Burkhart, J. F., Stohl, A., and Wennberg, P. O.: Patterns of $\mathrm{CO}_{2}$ and radiocarbon across high northern latitudes during International Polar Year 2008, J. Res.-Atmos., 116, D14301, doi:10.1029/2011jd015643, 2011.

WDCGG: WMO World Data Centre for Greenhouse Gases, Japan Meteorological Agency, Tokyo, available online at: http://ds. data.jma.go.jp/gmd/wdcgg/wdcgg.html (last access: 22 February 2013), 2013.

Witham, C. and Manning, A.: Impacts of Russian biomass burning on UK air quality, Atmos. Environ., 41, 8075-8090, doi:10.1016/j.atmosenv.2007.06.058, 2007.
Wofsy, S. C., Fan, S. M., Blake, D. R., Bradshaw, J. D., Sandholm, S. T., Singh, H. B., Sachse, G. W., and Harriss, R. C.: Factors influencing atmospheric composition over sub-arctic NorthAmerica during summer, J. Geophys. Res.-Atmos., 99, 18871897, doi:10.1029/93jd02256, 1994.

Wooster, M. J., Freeborn, P. H., Archibald, S., Oppenheimer, C., Roberts, G. J., Smith, T. E. L., Govender, N., Burton, M., and Palumbo, I.: Field determination of biomass burning emission ratios and factors via open-path FTIR spectroscopy and fire radiative power assessment: headfire, backfire and residual smouldering combustion in African savannahs, Atmos. Chem. Phys., 11, 11591-11615, doi:10.5194/acp-11-11591-2011, 2011.

Wotawa, G. and Trainer, M.: The influence of Canadian forest fires on pollutant concentrations in the United States, Science, 288, 324-328, doi:10.1126/science.288.5464.324, 2000.

Wotton, B. M., Nock, C. A., and Flannigan, M. D.: Forest fire occurrence and climate change in Canada, Int. J. Wildland Fire, 19, 253-271, doi:10.1071/wf09002, 2010.

Yokelson, R. J., Griffith, D. W. T., and Ward, D. E.: Openpath Fourier transform infrared studies of large-scale laboratory biomass fires, J. Geophys. Res.-Atmos., 101, 21067-21080, doi:10.1029/96jd01800, 1996.

Yokelson, R. J., Goode, J. G., Ward, D. E., Susott, R. A., Babbitt, R. E., Wade, D. D., Bertschi, I., Griffith, D. W. T., and Hao, W. M.: Emissions of formaldehyde, acetic acid, methanol, and other trace gases from biomass fires in North Carolina measured by airborne Fourier transform infrared spectroscopy, J. Geophys. Res. Atmos., 104, 30109-30125, doi:10.1029/1999jd900817, 1999.

Yokelson, R. J., Bertschi, I. T., Christian, T. J., Hobbs, P. V., Ward, D. E., and Hao, W. M.: Trace gas measurements in nascent, aged, and cloud-processed smoke from African savanna fires by airborne Fourier transform infrared spectroscopy (AFTIR), J. Geophys. Res., 108, 8478, doi:10.1029/2002JD002322, 2003.

Yokelson, R. J., Christian, T. J., Karl, T. G., and Guenther, A.: The tropical forest and fire emissions experiment: laboratory fire measurements and synthesis of campaign data, Atmos. Chem. Phys., 8, 3509-3527, doi:10.5194/acp-8-3509-2008, 2008.

Yokelson, R. J., Crounse, J. D., DeCarlo, P. F., Karl, T., Urbanski, S., Atlas, E., Campos, T., Shinozuka, Y., Kapustin, V., Clarke, A. D., Weinheimer, A., Knapp, D. J., Montzka, D. D., Holloway, J., Weibring, P., Flocke, F., Zheng, W., Toohey, D., Wennberg, P. O., Wiedinmyer, C., Mauldin, L., Fried, A., Richter, D., Walega, J., Jimenez, J. L., Adachi, K., Buseck, P. R., Hall, S. R., and Shetter, R.: Emissions from biomass burning in the Yucatan, Atmos. Chem. Phys., 9, 5785-5812, doi:10.5194/acp-9-5785-2009, 2009.

Yokelson, R. J., Andreae, M. O., and Akagi, S. K.: Pitfalls with the use of enhancement ratios or normalized excess mixing ratios measured in plumes to characterize pollution sources and aging, Atmos. Meas. Tech., 6, 2155-2158, doi:10.5194/amt-62155-2013, 2013. 